\title{
BY HER OWN AUTHORITY: THE SCOPE OF MIDWIFERY PRACTICE UNDER THE ONTARIO MIDWIFERY ACT, 1991
}

\author{
ELIZABETH MASSEY
}

To allow is to exercise as much. if not morc. power than to forbid."

\begin{abstract}
Midwifery is recognized as an automomous, selfgoverning professiom under Ontario's Midwifery Acl, 1991 and Regulated Health Professions Act. 1991. The author discusses the implications of this new legislation and addresses how the Acts define the nature and scope of midwifery pructice. Although the new regulatory onodel grams midwives legal and professional status. their staturon' scope of practice is limited (I) "normul" pregnancy. labour and deliven. Within the new regulatory framework, the authority ud define the meaning of "normal" remains with physicians. Therefore. the capacing to control the scope and arcilability of midwifen senvices lies in the hands of the medical profession. which has historically been opposed to the autonomous practice of miduifery.
\end{abstract}

The author explore's the other elements of the Midwifery Act, 1991 . such as matters of assessment and diagnosis. and issues of portential liability. and whether or not these could bind midwifery practice by estublished medicine within the Ontario health care system.

In implementing the Acts. much comsultation remains wo be dome amoms members of the relevant professional bodies and the public in balance competing interests and views, while ensuring quality. health care and comsumer choice.
En Ontario. l'exercice de snge-femme est ume profession autonome d après la Loi de 1991 sur les sages-femmes et la Loi de 1991 sur les professions de la sunté réglementées. L'auteure examine les implications de ces nouvelles lois et la fason dont elles définissemt la nature et le domaine d'application de la pratique. Bien que la nouvelle réglementuriom confere aux sages-femmes une certuine reconnaisisunce professionnelle et un statut juridique. leur pratigue se limite à la grossesse. ca travail et à laccouchement dits "nomauxw. Dans ce cadre. c'est aux médecins que revient la responsabilité de définir la norme. La capacité de contrôler le chamip et la prestation des services de sages-femmess se trouve donc entre les mains du corps des médecins qui s'i'st toujours opposé à l'exercice automome des sages-fenmes.

Licuseure explure les autres éléments de la Loi sur les sages-femmes. notamment les questions d'évaluation et de diagnostic. et celles de responsubilité éventuelle; il sagit également de déterniner si ces considérations pourraient lier la profession de sarge-fermme à la médecine établie au sein du système de sunté onturien.

L'entrée en vigueur de ces lois devra domner lieu à de nombreuses consultations parmi les membres dess professions concernees et le public si l'on veut pan'enir à équilibrer les intéréts et points de 'vue concurrents fout en ussurant la qualité des soins "t la liberie de choix du consommateur.

\section{TABLE OF CONTENTS}

I. INTRODUCTION .................... 350

11. HISTORY AND DEVELOPMENT OF MIDWIFERY $\ldots \ldots \ldots 351$

A. HISTORICAL BACKGROUND OF MIDWIFERY IN CANADA . ............ 351

B. LEGAL BACKGROUND OF MIDWIFERY IN CANADA $\ldots \ldots \ldots \ldots \ldots \ldots \ldots \ldots \ldots \ldots \ldots \ldots \ldots \ldots$

Student at Liw, Soloway, Wright. Otlawa.

- $\quad$ R.D. Laing, psychiatrist, quoted in P.S. Eakins, "Introduction" in P.S. Eakins, ed., The Americun Way of Birth (Philadelphia: Temple University Press, 1986) 3 at 13. 
C. DEVELOPMENT OF MIDWIFERY AS AN

AUTONOMOUS PROFESSION IN ONTARIO . . . . . 356

III. MIDWIFERY AND THE NEW LEGISLATION $\ldots \ldots \ldots \ldots \ldots 358$

A. THE MIDWIFERY ACT, 1991 AND RELATED

SECTIONS OF THE REGULATED HEALTH

PROFESSIONS ACT, $1991 \ldots \ldots \ldots \ldots \ldots \ldots \ldots . \ldots 28$

B. MIDWIVES' AUTONOMY AND SCOPE OF

PRACTICE UNDER THE MIDWIFERY ACT, $1991 \ldots \ldots \ldots 364$

C. ASSESSMENT AND DIAGNOSIS OF

NORMAL AND ABNORMAL CONDITIONS . . . . . . . 367

D. ASSESSMENT WITHIN MIDWIFERY'S

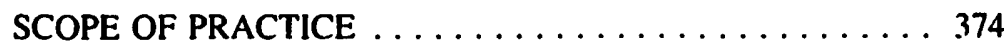

E. THE AUTHORITY OF MIDWIVES

TO COMMUNICATE . . . . . . . . . . . . . 376

F. THE RELATIONSHIP BETWEEN LIABILITY UNDER

SECTION 30 OF THE RHPA AND ACTING OUTSIDE

THE SCOPE OF MIDWIFERY PRACTICE $\ldots \ldots \ldots \ldots 380$

IV. THE IMPLEMENTATION OF THE MIDWIFERY ACT $\ldots \ldots \ldots 383$

A. THE RELATIONSHIP BETWEEN MIDWIVES

AND OTHER HEALTH PROFESSIONALS $\ldots \ldots \ldots \ldots . \ldots 383$

B. THE LOCATION OF THE PRACTICE

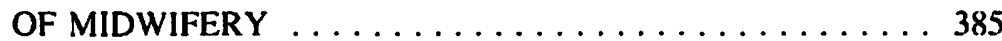

V. THE FUTURE INTEGRATION OF MIDWIFERY

AS A REGULATED HEALTH PROFESSION WITHIN

ONTARIO'S HEALTH CARE SYSTEM $\ldots \ldots \ldots \ldots \ldots \ldots . \ldots 387$

VI. CONCLUSION ...................... 389

\section{INTRODUCTION}

The Ontario Midwifery Act, 199/' and the Regulated Health Professions Act, 1991' establish midwifery as a self-governing health profession with an autonomous scope of practice. Ideally, legal recognition and professional autonomy will enable midwifery to overcome historical opposition by established medicinc and ensure that the practice of midwifery is not dictated by external norms and undue restrictions.

It is not clear. however, whether the statutory definition of the scope of midwifery practice will enhance or undermine the integrity and independence of midwives in Ontario. The Midwifery Act recognizes midwives as autonomous, primary care-givers for women experiencing normal pregnancy, labour and delivery. But the legislation does not clarify the meaning of "normal" and, therefore, leaves the scope of autonomous midwifery

S.O. 1991, c. 31 |hereinafter. the Midwifery Ac'l the Midwifen Act received royal assent on November 25. 1991. Section 12 of the Act has been in force since that date and the remainder will be in effect on proclamattion.

$=\quad$ S.O. 1991, t. 18 /hereinafter RHPA|. Sections $1(1), 7,8,9,10,11(1)(c), 14,15,16.17$ and 38 of the RHPA were proclaimed in force. effective August 1, 1992. The remainder of the new health professions legislation is expected to be proclaimed hy the end of 1993. 
practice uncertain. Ultimately, the power to define the bounds of normal and of midwifery practice lies in the hands of physicians who, under the new legislation, retain the exclusive authority to diagnose abnormal conditions in pregnancy and childbirth. Consequently, while the aim of the Midwifery Act is to admit midwives as equal partners into the health care system, the continued predominance of medical expertise and authority may perpetuate past struggles over professional domain and result in the estahlishment of midwifery on physicians terms.

\section{HISTORY AND DEVELOPMENT OF MIDWIFERY}

\section{A. HISTORICAL BACKGROUND OF MIDWIFERY IN CANADA}

In the western world, midwifery presents one of the earliest examples of professional regulation and interprofessional competition. The current dispute between midwives, nurses and physicians continues a historic power struggle based on different philosophies of childbirth experience. There has been a long history of competition between community-based health care and that offered by hospital-centred physicians and nurses. ${ }^{3}$

Midwifery's approach to childbirth is essentially holistic and non-interventionist. Childbirth is viewed as a natural process rather than a pathological state. Women are not treated as ill patients but receive care throughout the pregnancy, birth and post-partum period. By contrast, obstetrics, the branch of medical science concerned with childbirth and the treatment of women before and after childbirth, tends to regard childbirth as a pathology or illness requiring hospital care and the use of medical technology and intervention. ${ }^{4}$

Conflict between orthodox medical practice and informal midwifery practice emerged during the Middle Ages. A woman healer, who practised without accepted training, could be prosecuted as a witch by Church authorities and punished by death. "If a woman dare to cure without having studied she is a witch and must die," declared the Reverends Kramer and Springer of Germany in 1484."

By the mid 15th century, it was customary in Europe for midwives to be examined by members of the established medical profession on methods and procedures. During the 17th century, the expertise of male midwives and physicians was enhanced due to the invention in the early 1600 s of forceps, which were particularly useful in assisting difficult deliveries. The increasing use of surgical instruments, allowed only to licensed practitioners, widened the gulf between midwives, whose training remained essentially experiential and informal, and physicians whose training tended to treat birth as a medical problem to be solved.

\footnotetext{
M. Baker, Midwiferr: A New Status (Ottawa: Library of Parliament. Rescarch Branch, 1989) at 2. L. Jexioranski, "Towards a New Status for the Midwifery Profession in Ontario" (1987) 33 McGill L.J. 9) at 92-93.

Reverends Kramer and Springer, "Malleus Maleficarium. 1484" in B. Ehrenreich and D. English. Wirrhes. Midwives and Nurses: A Histun of Women Healers (Old Westbury. New York: The Feminist Press. 1973) at 19.
} 
The history of midwifery in Canada may be seen as "the story of a highly developed birth culture, surprisingly similar in both native and settler populations, that was gradually eclipsed by expanding medical control over childbirth." In Canada, during the first forty years of this century the established medical professions, including physicians and nurses, carried out a systematic public education campaign to convince women that childbirth was safer in hospitals than in the home. ${ }^{7}$ However, the progression from traditional birth culture to modern obstetrics was effected at a time when "medically-managed birth in hospital appears to have been statistically more dangerous than birth carried out at home in the traditional manner. ${ }^{\text {"8 }}$ There is some doubt about the reliability and validity of the statistics of birth-related mortalities at that time. However, the Task Force on the Implementation of Midwifery in Ontario argued that modern obstetrics superseded midwifery, not on the grounds of safety, but on the basis of the beliefs of the proponents of obstetrics. ${ }^{9}$

Nonetheless, some historians have pointed out that the decline of midwifery is not simply a case of one discipline being superseded by another. As the Ontario Task Force Report has pointed out: ${ }^{10}$

To ask why midwives were not able to form themselves into an enduring profession in Canada. then, is to ask the wrong question. It is not that midwives those many neighbour women who helped another in childbirth lacked the imagination or the energy to build a profession that could challenge the doctors. It is that their imagination and their culture gave them a different vision... (one in which) childbirth belonged to the community.

In the last twenty years there has been considerable interest in midwifery in Canada. Women are becoming increasingly aware that the prevalent view of childbirth as a "medical event" rather than a natural process and of pregnant women as "patients" rather than "clients" leaves much to be desired. Women giving birth are expressing their dissatisfaction with what has become a "highly technical, interventionist, physiciandominated hospital delivery system. In addition, social movements for women's rights and [patients' rights] have contributed to an increasing public demand for greater control over health care services, including maternity care." "Among the recommended changes are a review of the legal status of midwifery and of the uses of alternative birth settings such as birthing centres and the home. These reforms would also have the effect of strengthening the voice of women, their families and the community in the birth process.

Report of the Tusk Force on the Implementation of Midwifeny in Ontario (Toronto: Ontario Ministry of Health. Ontario Ministry of College and Universities, 1987) at 197 (hereinafter Ontario Task Force Report|.

I Ibid. at 212.

* Alberta. Health Disciplines Board Investigation of Midwifery: Final Report and Recommendations (Edmonton: Solicitor General. 1991) at 8-9 (hereinafter Alberta Health Disciplines Board Repurl).

$4 \quad$ Ontario Task Force Report, supra note 6 at 198.

1"I Ibid. at 198.

" Alberla Health Disciplines Board Report, supra note 8 at 11. 


\section{B. LEGAL BACKGROUND OF MIDWIFERY IN CANADA}

The 1991 report of the Alberta Health Discipline Board's Inquiry into midwifery surveyed the Canadian provincial and territorial govemments about the status of midwifery in their respective jurisdictions. All reported that they had no legislation which permitted midwives to practice without the supervision of physicians. Some, such as British Columbia and Ontario, reported that the acceptability and regulation of midwifery were under review.'2 Despite the absence of legislation (or limited legislation in the case of Newfoundland) allowing midwifery in Canada, the Alberta Health Discipline Board Report points out that "300 to $\mathbf{4 0 0}$ midwife attended births are occurring in British Columbia each year.... In northem Newfoundland and Labrador, there are specially trained nurses who practise midwifery in cooperation with, or under the supervision of, physicians." ${ }^{13}$ In the Northwest Territories. the government policy of transporting pregnant women to regional health centres for childbirth has led to "dissatisfaction of families and communities, (and) resulted in an interest and call to revitalize midwifery services." ${ }^{\prime 4}$ The NWT Department of Health, as a result of the concerns mentioned above, recommended that two pilot projects on midwifery be implemented and that the development of legislation concerning midwifery be considered."

In Quebec, a Commission of Inquiry into Health and Social Services prepared a report on midwifery in 1988. This report and a provincial Task Force on midwifery recommended that midwifery be granted legal recognition. In addition, an Advisory Council on Social Affairs urged the government to establish a pilot project for three years to allow midwives to deliver selected low risk births. In June 1990, the Quebec Government approved Bill 4 which allows midwifery to be practised for six years in eight pilot projects affiliated with Quebec's health care system. ${ }^{16}$ The aim of the Act is to determine whether the practice of midwifery will be allowed and under what circumstances. Under the terms of the Act, midwives in the pilot projects will be allowed to practice without a physician's direct supervision and patients may consult with midwives directly. ${ }^{17}$ The pilot projects will be carried out only in hospitals (i.e. no home births) and a woman may use the services of a midwife only if her pregnancy is determined to be "low risk." However, the criteria for determining which pregnancies are low-risk and who is to make that determination are not provided in the Act. ${ }^{18}$

1: Ibid. at 23-25. Since 1991. New Brunswick and Manitoba have also underaken studies concerning the regulation of midwifery. In Albertia. midwives will receive legal recognition under existing health professions legislation. although the necessary regulations have not yet been written. Ontario Ministry of Health. "Backgrounder: Notes on Midwifery" (Toronto: March 29. 1993) at 2.

$13 \quad$ bid. at 24.

it Letter from Ms. Maureen Morewond. Assistant Director. NWT Health. to the Alberta Health Disciplines Board. (8 June 1990) ibid. at 25.

15 Ihid. at 25.

15 All Act Respecting the Practice of Midwifery within the Framework of Pilot Projects. S.Q. 1990. c. 12.

17 Orfice des Professions du Quehec, Midwifery Brief submitted (o Alherta Health Disciplines Board. Alberla Healih Disciplines Beard Report. supra note 8 at 26. 
Prior to the Midwifery Act, 1991 and its legal recognition of midwives, Ontario did not expressly outlaw the practice of midwifery. Instead the Health Disciplines Act, R.S.O. 1990 c. H-4 prohibits anyone but a medical doctor licensed by the College of Physicians and Surgeons of Ontario from practising medicine. While not defined exhaustively, the term "medicine" in the Act does include obstetrics. Under the Health Disciplines Act, an Ontario midwife could face prosecution for practising medicine without a licence. ${ }^{19}$ In 1987, the Task Force on the Implementation of Midwifery in Ontario observed: ${ }^{20}$

It could be argued in her defence that the practice of midwifery is not the same as the practice of obstctrics and that she, therefore, does not require a licence. As far as we are awarc, no midwife has been prosecuted in Ontario for practising medicine without a licence since the early part of this century and whether midwifery is included in the practice of medicine has been made moot with the government's decision to recognize and regulate midwifery.

Also, midwives could face criminal prosecution for criminal negligence under s. 219 et seq. of the Criminal Code, R.S.C. 1985, c. C-46, for the failure to perform a duty likely to cause the health of that person to be endangered permanently.

Notwithstanding lack of legal status, restrictive legislation and a hostile medical profession, midwives in Ontario have continued to practice privately, providing prenatal care and delivering babies. As Anne Maranta, a Kingston, Ontario midwife, observes, while for the most part midwifery was pushed aside at the turn of the century, some areas of Ontario have always had midwifery care (e.g. remote, rural, native and Mennonite communities)." Midwives do attend births at home. However, for clients who choose hospital births, midwives may act only as labour coaches since they have no recognized status in hospitals. ${ }^{22}$ Ms. Kilpatrick, a representative of the Association of Ontario Midwives (AOM) stated in August 1991:23

The practising midwife membership in our Association is around 60. Our non-practising midwife membership is |currently| fairly low. around 25 . There are probably thousands of trained midwives from numerous other countries.

It is reported that, world-wide, $75 \%$ of the babies born today are delivered into the hands of midwives. ${ }^{24}$ The World Health Organization's statistics show that Canada and

\section{Baker, supra note 3 at 18.}

Ontario Task Force Report, supra note 6 at 74.

Interview with Anne Maranta, Kingston, Ontario, midwife (12 June 1991) |hereinafter Maranta Intervicw - 1991].

K. Kaufman. "The Introduction of Midwifery in Onturio, Canada" (1991) 18 Birh 100 at 100 [hereinafter K. Kaufman, Birth].

Ontario, Legislative Assembly, Standing Committec on Social Development, "Regulated Health Profession Act, 1991 and Companion Legislation" in Debutes, No. S-10) at S-293 (7 August 1991) |hereinafter Debates].

D. Martin. "The Control of Reproduction: State Regulation of Midwifery in Ontario: A Feminist Challenge" in Canadian Bar Asscxiation - Ontario, Feminist Analysis II (Toronto: CBAO, 1993) at 1. 
seven developing nations do not provide "comprehensive legal midwifery care during normal childbirth." ${ }^{25}$ The World Health Organization states that a midwife is to be:"2h

trained to give necessary eare and advice to women during pregnancy. labbrur and the postnatal period. to conduct normal deliveries on her own responsibility, and to care for the newly born infant. At all times she must be able to recognize the warning signs of abnormal or potentially abnormal conditions which necessitate referral to a doctor. and to carry out emergency measures in the absence of medical help.

This description, however, does not convey the adverse and unique nature of the practice of midwifery which can address the physical, emotional and even spiritual aspects of childbirth. In describing her experiences as a midwife. Anne Maranta states, "my role as a midwife encompasses education, care and support throughout the whole childbearing years."27 This might include community education, family counselling, birth-control counselling, postpartum care and support beyond the normal postpartum period. The hallmark of midwifery is the continuity of care based on a supportive relationship of parity between the midwife and the woman.

In Ontario, the passage of the Miduifery Act and the reform of health professions' regulation are a response to the growing demand for stronger consumer roles in health care and to widespread criticism of the historical approach of medicine to pregnancy and birth. Traditionally, the medical profession views pregnancy as a pathological condition fraught with potential risk. Pregnant women are regarded as unwell, passive and dependent upon the intervention of medical science. In hospitals, amniotomies, analgesics. fetal monitoring. episiotomies and caesarean sections are often routine. ${ }^{2 \mathrm{k}}$ One woman recalls, "I remember being shaved, given an enema. I remember a sea of masked faces, none of whom I recognized except my husband's and my doctor's." ${ }^{3)}$ Recently, the Canadian Medical Association (CMA), responding to increased demands for midwifery services, claimed, without citing evidence, that $90 \%$ to $95 \%$ of women are satisfied with the existing system. The CMA has argued there is no need to "complicate" a crowded health care system by legalizing midwifery as an alternative approach to the birth process."

In contrast, midwives view their female clients as autonomous, healthy women who have chosen the services of a midwife as an alternative to medical practice. which is viewed by critics as excessively involved in the birth process and unresponsive to women's wishes. Moreover, it is argued that an aggressive interventionist approach to all birth increases risks to mother and child. The growing demand for regulated midwifery

Manitoba Advisory Council on the Status of Women. Midwifery: Recommesndations: to the Manilohes Governme'nl (Winnipeg: Maniluba Advisory Council of the Status of Women. 1988) al 6. P.J. Slewart \& J.M. Beresford. "Opinions of Physicians Assisting Births in Ottawa-Carleton Ahout the Licensing of Midwives" (1988) 1.39 Canadian Medivel Associanion Jourmal 393 at $39.3-394$. Maranta Interview - 1991 . stupra note 21.

$\therefore \quad$ L. Jesioranski. supra nolle 4 at 9.3.

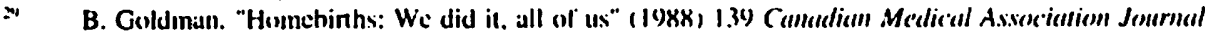
773 it 773.

.4 Staff. "Ontario Task Fore Disagrees with the Canadian Medical Association about the Necd for Midwilery" 11987, 1.37 Camaliem Medical Adsociation Jonrmal 1.321 at 1.321. 
services is part of a movement for the recognition of "health care by and for women." ${ }^{31}$ Midwives regard pregnant women as healthy consumers of health care who, when fully informed and educated, will decide which available options are appropriate.

Demand for changes in maternity care grew in Canada during the 1970s and 1980s reflecting increased interest in continuity of care and choice of birth place. In the eyes of many concerned consumers, midwives were the only health care provider to offer comprehensive care throughout the childbirth process: prenatally, during labour, birth and in the postpartum period. Midwifery care was intrinsically responsive to consumer needs. It offered the informed choice agreement, recognizing the role of the woman and her family as decision makers. ${ }^{32}$

Midwives, their clients, and supporters are demanding that women control, through a greater voice and an active role, the management of pregnancy and childbirth. ${ }^{33}$ Vicki Van Wagner, of the Midwives' Collective of Toronto and the AOM, describes the revival of the midwifery profession "as a radical challenge to medical control of childbirth. ${ }^{.34}$ In recent years midwives, by continuing to practice outside the sanctioned health care system, have worked to redefine pregnancy and birthcare in women's terms. ${ }^{35}$

\section{DEVELOPMENT OF MIDWIFERY AS AN AUTONOMOUS PROFESSION IN ONTARIO}

In Ontario, "the strategy of the midwifery movement has been to create highly visible practice outside the health care system, while pressuring for legislation, autonomy, government funding and access for all women.".36 The survival of midwifery practice provided a foundation for the campaign for legal recognition of midwifery as an autonomous profession. On this foundation midwives were able to form the Association of Ontario Midwives and establish standards for training and practice. ${ }^{37}$ The tenacious strategy of offering midwifery services in spite of legal, political and financial obstacles (for example, midwifery fees were not funded by the Ontario Health Insurance Plan) enabled midwives to claim legal recognition as a result of demonstrated demand for their services and the "immediate pressure" they were able to exert on legislators" opinions. ${ }^{3 k}$ During the 1980s, as Karyn Kaufman, a former Implementation Co-ordinator for Midwifery with the Ontario Ministry of Health, notes: ${ }^{31}$

M. Weisensee. "Women's Health Perceptions in a Malc-Dominaled Medical World" in D.K. Kjervck \& 1.M. Martinson. eds.. Women in Heallh and Illness: I.ife Fixperiences and Crises IToronto: W.B. Saunders Company. 1986) 19 at 24.

Midwifcry Task Force Onturio. Submission to the Standing Committee on Social Development, Exhibit No. N 1/05/207 at 3-4 (19 August 1991).

Ibid.

V. Van Wagner, "Women Organizing for Midwifery in Ontario" (1988) 17 Resources for Feminist Resecurch 115 at 115.

Ibicl.

Ibill.

Ihid.

Ibiel.

K. Kalufmatn. Birth. supra nute 22 at 101. 
Practising midwives across the province had voluntarily taken on the lasks of setting standards, conducting peer reviews and establishing a complaints and discipline procedure. The willingness and ability to undertake self-regulation were important contributors to the government's decision to include midwives in the legislative framework for self-regulated professions....

Midwives moved closer to legal recognition in 1984 with the introduction in the Ontario Legislature of Bill 48 by opposition member David Cooke. The bill sought to establish midwifery as an independent, self-governing profession. ${ }^{+0}$ However, the Bill was not passed. In January 1986, the Minister of Health announced that the Ontario govemment would regulate midwifery. Prior to this announcement, the government had established in 1983 a Health Disciplines Review Committee. Its function was to report on the regulation of new and existing health disciplines as well as to "update and reform the Health Disciplines Act and to devise a new structure for all legislation governing the health professions which would settle outstanding issues involving several professions." ${ }^{\text {"4l }}$

Following the 1986 announcement that the Ontario Government would regulate midwifery, a government task force was established to examine the practice of midwifery, its standards, training and the professional legislation in other countries such as the United States, the Netherlands and the United Kingdom. ${ }^{42}$ The Task Force on the Implementation of Midwifery in Ontario studied "places where midwives function autonomously and have clearly defined roles in the health care system, as well as places where midwives have difficulty functioning to their full potential and find their roles threatened or not yet fully realized." ${ }^{4.3}$ The work of the task force parallelled the ongoing study by the Health Profession's Legislative Review, established in November 1982, in that it was asked to examine such topics as midwives' training, professional entry requirements, scope and standards of practice, governance, location, hospital status and to what degree midwives should practice independently and under supervision.

In its 1987 report, the Task Force recommended ${ }^{\text {th }}$ that midwives should operate as independent practitioners without supervision by physicians and that midwifery should not be considered as a specialty of nurses' training under the direction of nursing organizations. It recommended self-government for midwives with a governing council and a College of Midwives to set standards and the scope of practice based on international definitions. It also proposed that a baccalaureate degree in midwifery be the requirement for entry into practice. ${ }^{45}$

At the end of 1988, the Health Professions Legislation Review presented its draft legislation containing a new scheme to regulate health professionals including

\footnotetext{
M. Baker, supru note 3 al 18.

L. Bohnen, Debates, supra note 23. No. S-9 at S-243 (6 August 1991).

K. Kaufman, Birth. supra note 22 al 100.

Ontario Task Force Report. supra note 6 at $\mathrm{II}$.

Ihid. al 20-22.

K. Kaufman. Birth. supra note 22 at 101.
} 
midwives. ${ }^{46}$ In response to public and professional support for the Task Force's recommendations, the Interim Regulatory Council on Midwifery (IRCM) was appointed in May 1989, to advise the Minister of Health. The IRCM has worked since with the Association of Ontario Midwives and consumers to lay the groundwork for standards, procedure and certification requirements and other pre-requisites for establishing midwifery as a self-governing profession.

The Midwifery Act and the Regulated Health Professions Act, 1991 (hereinafter RHPA) follow from the above recommendations and were passed to establish midwifery as an autonomous health care discipline in Ontario. As will be seen below, these Acts do not ensure that midwives may practice independently and, in particular, without undue control by physicians. Several issues relevant to this question of professional autonomy for midwives remain unclear under the terms of the Acts. These issues include the distinction between normal and abnormal births and the relationship of medical diagnosis to a midwife's assessment and communication of a client's condition.

\section{MIDWIFERY AND THE NEW ONTARIO LEGISLATION}

\section{A. THE MIDWIFERY ACT 1991 AND RELATED SECTIONS OF THE REGULATED HEALTH PROFESSIONS ACT, 1991}

The Regulated Health Professions Act, 1991, (RHPA) and twenty one professional Acts, including the Midwifery Act, received Royal Assent on November 25, 1991 and will come into effect with proclamation expected to occur before the end of $1993 .{ }^{47}$ These laws are the legislative foundation for the integration of midwifery, with its own College of Midwives, as a self-governing profession within Ontario's health care system. Midwives will define the terms of their professional self-governance by writing regulations and bylaws concerning standards, qualifications and discipline.

In October 1991, the Ontario Government announced the establishment of midwifery educational and pre-registration programs. The pre-registration program, begun in the Fall of 1992, will enable currently practising Ontario midwives to meet eligibility criteria for registration with the College of Midwives.

The educational program in midwifery will be a post-secondary program beginning in September 1993, and will include significant clinical work. However, Linda Bohnen, of the Ministry of Health, has indicated that the program will not use an apprenticeship system but will be "based on professional midwifery education in an educational institution" with some components of the training offered in other settings such as hospitals. ${ }^{48}$ The Ministry of Health is currently reviewing the Public Hospitals Act and

Health Professions Legislation Review, Striking a New Balance: A Blueprint for the Regulation of Onturio s Health Professions (Toronto: Ontario Ministry of Health, 1989) (hereinafter Striking a New Balancel.

47 Ontario Ministry of' Heulth, "Fact Sheet, the Regulased Health Professions Act, 1991" (28 November 1991).

4* L. Bohnen, Deburess, supra notc 23. No. S-20) at S-649 (26 August 1991). 
discussing models for the funding of midwives' services. It is anticipated that provisions will be made to cnable midwives to obtain hospital privileges so that they can train and practise in hospitals and admit clients. ${ }^{44}$

The achievement of the legal recognition of midwifery as an autonomous college of specialists in normal births has brought women closer to equality in the health care system. The changes to the Ontario legislation mark a break from a system of professional regulation dominated by men. The seven new professions to be regulated within the RHPA consist predominantly of female members. They are audiology, dietetics, medical laboratory technology, occupational therapy, respiratory therapy, speech-language pathology and midwifery.

The new legislative framework retains the primary policy objectives articulated by the Health Professions Legislation Review. These objectives are public protection, high quality and cost-effective delivery of health services, freedom of choice and the flexible evolution of health care professions which have equal status within the regulatory system. ${ }^{50}$ Above all, regulation of health care practitioners is intended to promote the public, and not the professional, interest." To this end, the RHPA creates the Health Professions Regulatory Advisory Council, a group of non-professionals who will monitor the delivery of health care to ensure the system's continued quality and responsiveness.

The scope of practice definition and the list of authorized acts contained in the new legislation establish an innovative model of self-government which moves away from exclusive licensure of professional practice. This model recognizes the current reality of a multidisciplinary health system in which the scopes of practice of various professions overlap. The self-government of a single profession is based on co-operation and consultation with other professionals, public bodies (such as the Health Professions Regulatory Advisory Council), hospitals and branches of government. Each profession will operate with a package of other professions and groups which share its aims and objectives rather than in a fragmented way as in the present outmoded system. As Striking a New Balance states:

The existing systcm. in which a small number of health professions arc "licensed" (their members have an exclusive licence or monopoly over the provision of services that fall within their scope of practice) and others are "registered" (their members have the exclusive right to usc ccrtain titles), does not effectively protect the public from unqualified health care providers. As well, it has undesirable effects on the health care system. In particular, it inhibits innovation in the way various health professions can be utilized. making it more difficult to provide the hest service at the lowest cost.

The RHPA standardizes professional regulation so that the self-government of midwives, for example, is equal to that of physicians, nurses and other professions.

Interview with Helen McDonuld, then the Ontario Government Midwifery Implementation Co-ordinator (2 March 1992) |hercinafter McDonald Intcrview|.

Supra note 46 at 2.

Ihid.

lbid. at 3. 
Midwives can participate as full and respectable members of the Ontario health care system. Within the new legislative framework, midwives have, in their scope of practice, education and regulatory provisions the same measure of autonomy as the members of any other of the regulated health care professions. Ideally, professional autonomy will provide midwives with the ability to ensure that external norms and restrictions do not dictate the nature and scope of midwifery practice within the health care system. The privileged status of a self-governing profession is based on the primary responsibility to protect the public's interest. The mandate of the College of Midwives of Ontario is to achieve this objective by ensuring that midwives provide the highest quality of care.

A major component of the autonomy of midwives and their relationship to physicians, nurses and other health care providers is the RHPA. This Act will replace the prohibitions in the Health Disciplines Act regarding the unlicensed practice of medicine with a new scheme of thirteen categories of "controlled acts" which only a physician or, in some cases, another regulated health professional, may legally perform. ${ }^{53}$ The list of controlled acts that each health profession is authorized to perform is set out in that health profession's governing Act. The controlled acts are those that have been classed as potentially harmful. By eliminating the old system, which delineated a sphere of practice and created a professional monopoly, the new legislation is intended to provide a balanced framework of increased consumer choice, public protection and professional autonomy.

The Health Professions Legislation Review stated that "articulating licensed acts will provide better definition of the border between exclusive and non-exclusive practice.".".4 Under the previous system of regulation, only a person licensed by the governing body could practise lawfully within the profession's scope of practice, which included both harmful and unharmful acts. By controlling and enforcing only those acts which are potentially hazardous and by explicitly defining relative scopes of practice, the new legislation seeks to promote greater flexibility in the delivery of health care with fewer professional turf battles. ${ }^{55}$

This legislative scheme licensing only harmful, "controlled" acts is intended to produce improved regulation of health care professions. Governing bodies will be better able to enforce their license provisions against unregulated practitioners since the controlled acts are explicitly stated. Secondly, clearer guidance is available to the courts when they determine the extent of professional monopoly. In addition, unregulated and regulated practitioners who do not have explicit authorization to perform certain controlled acts will better understand the limits of their own practice. ${ }^{56}$

Subsection $27(1)$ of the RHPA restricts the performance of controlled acts, stating:

No person shall perform a controlled act set out in subsection (2) in the course of providing health cure services to an individual unless

"RHPA. s. 27(2)(1).

A. Burrows. Debates. supra note 23, No. S-9 at S-247 (6 August 1991).

ss $\quad$ bid.

s. Ibid. 
a) the person is a member authorized by a health profession Act to perform the controlled act; or

b) the performance of the controlled act has becn delegated in accordance with s. 28 to the person by a member described in clause (a).

A person who contravenes subsection $27(1)$ is guilty under s. $40(1)$ of an offence and "on conviction is liable to a fine of not more than $\$ 25,000$ or to imprisonment for a term of not more than six months or to both."

Section 30 provides that:

(1) No person, other than a member treating or advising within the scope of practice of his or her profession, shall treat or advise a person with respect to his or her health in circumstances in which it is reasonably foreseeable that serious physical harm may result from the treatment or advice or from an omission from them.

(2) Subsection (1) does not apply with respect to treatment by a person who is acting under the direction of or in collaboration with a member if the treatment is within the scope of practice of the member's profession.

(3) Subsection (1) does not apply with respect to an act by a person if the act is a controlled act that was delegated under section 28 to the person by a member authorized by a health profession Act to do the controlled act.

(4) Subsection (1) does not apply with respect to counselling about emotional, social, educational or spiritual matters....

Section 40 also applies to a breach of s. 30 . Consequently, a member of a regulated profession may breach the RHPA by performing, without authority, a controlled act assigned to another profession. In addition, a registered midwife who advises or treats outside the scope of practice as stated in section 3 of the Midwifery Act may be scrutinized under section 30 of the RHPA where she performs an act in circumstances in which it is "reasonably foreseeable" that serious harm may result from the treatment or advice or from an omission from them (s. 30(1)). The RHPA is the omnibus Act which contains the uniform regulatory structure applicable to all health professions.

Within this structure, the Midwifery Act establishes the governing College of Midwives and defines the title of "midwife." Section 8 of the Midwifery Act restricts the use of the title "midwife" to members of the College of Midwives. Aboriginal persons providing traditional midwifery services may practise as "aboriginal midwives" (s. 8(3)) independent of the College and outside the legislation. Also, the RHPA does not apply to aboriginal midwives and healers providing care to aboriginal communities (s. 35). Essentially "the government has recognized the importance of native peoples retaining control of traditional aboriginal midwifery services. ${ }^{.57}$ 
Liability for unauthorized activity is distinct from liability for malpractice or competence. Prior to the new legislation, midwives could not, without risk of legal sanctions under the Health Disciplines Act, engage in acts interpreted as within the practice of medicine. The RHPA and the various professional Acts do not purport to license the practice of a given profession. ${ }^{\text {sk }}$ They merely licence certain specified functions that are deemed to pose a greater risk of harm if unregulated. The aim of the Acts is to permit flexible professional roles, the sharing of tasks and the evolution and overlapping of boundaries. However, the scope of midwifery practice described in section 3 is not simply descriptive: it effectively circumscribes the capacity of midwives to perform legally those acts authorized in section 4. A midwife who performs, in circumstances outside the scope of midwifery practice, an act listed in section 4 may violate section $27(1)$ of the $R H P A$ and risks facing a charge under section $30(1)$ of that Act.

In 1991, the Ontario Minister of Health. Francis Lankin, stated that "midwives will get the credibility they deserve within the mainstream system. ${ }^{\text {"S9 }}$ The Midwifery Act was passed to establish an autonomous sphere of midwifery practice within the bounds of sections 3 and 4 of the Act. The committees of the College of Midwives will include government-appointed non-midwives to provide general public participation in a manner similar to all professional governance, but midwives will be a majority on all governing committees (ss. 6-14). The Act has been described as "one of the strongest statements of legislative support for an autonomous profession of midwifery anywhere in the world."(t) While important issues such as fee structure and hospital admitting privileges remain under review, Ontario midwives have achieved a measure of independence and selfgovernance by being designated and regulated on the same terms as other health professions. Ideally, midwives and their supporters anticipate that this enabling legislation will grant members of the profession a distinct role in the health care system as registered experts in normal, low risk childbirth. Midwives welcome the opportunity to establish a co-operative collegial relationship with physicians and other health professionals. "One of the greatest challenges emanating from the passage of this legislation will be the way in which professionals adjust to new working relationships" in this reformed multidisciplinary approach to the regulation and delivery of health care."

Undoubtedly, professional regulation will benefit both midwives and childbearing women. Midwives will obtain de jure legitimacy, a higher community profile and an increased ability to function. Clients of midwives will be able to choose alternatives to current maternal health services.

Nonetheless, some midwives have expressed "mixed feelings" about the future of midwifery training and practice under the new regulation. For example, questions have been raised concerning the university-based midwifery degree program proposed by the

4 Striking a New Balance. supra notc 46 at 3.

54 L. Pricst. "Midwifery to Become University Program" Toronto Stor (16 October 1991) A9 al A9.

(4) D. Martin, supra note 24 at 17.

(1) Toronto Birh Centre. Supplementary Submission to the Stunding Committec on Social Development. Exhibit No. A 1/05/139A (14 August 1991). 
Midwives' Curriculum Development Committee and its effect on the community roots of midwifery. Anne Maranta states, ${ }^{\text {,2 }}$ "there is concern among some midwives that the way we became midwives in the past (which) was to apprentice to senior midwives... may no longer be available if the university is the only route that's acceptable for licensure." Rural and native women as well as women with families often cannot relocate to urban university centres or cannot afford full time university fees.

One of midwifery's strengths is its ability to respond directly to community needs. It is the rural and native women who have traditionally formed the "profession" of midwifery in their communities and who may now be excluded by the formal requirements of "legitimacy." Many midwives are unwilling to adopt a single homogeneous professional model. Professionalism of midwifery could undermine its very nature as a flexible, responsive, community-based service. Barbara Ehrenreich and Deidre English caution: ${ }^{63}$

Professionalism in medicine is nothing more than the institutionalization of a malc. upper class monopoly. We must never confuse professionalism with expertise. Expertise is something to work for and to share: professionalism is... elitist and exclusive, sexist, racist and classist.

There are variations in the practice of midwifery in Ontario. Some midwives are more technological than others and some incorporate spirituality into their practice. Some see midwifery as a profession, while others see it as a way of life. There is concem over how the diverse, community-focused practice of midwifery will mesh with a proposed university degree program, fee structures, certification measures and other aspects of selfregulation. Notwithstanding the protection of title afforded by section 8 of the Midwifery. $A c t$, the term "midwife," as Anne Maranta says, "is a term that's owned by women and I don't think the government can take that term and make (it) illegal for other people to use that term (which) has been used for centuries. The greater body of midwives feel that diversity is what makes midwifery unique in this Province." ${ }^{16}$ Despite the new legal status, the successful implementation of midwifery as an autonomous, unique profession depends on whether the integrity of midwives' definition of childbirth care can exist within the bounds set by the enabling legislation. Jenny Farfard, as a member of the Coalition of Ontario Midwifery and Birth Schools, stated in August 1991: "to structure midwifery in the same hierarchical manner as other health disciplines is to undermine the very reason for its existence. ${ }^{165}$ Midwives' present dilemma over self-regulation is rooted in the past struggle by midwives and their supporters to assert and sustain, in a variety of ways, the practice of midwifery as a vital contribution to quality health care. 
[VOL. XXXI, NO. 2 1993]

\section{B. MIDWIVES' AUTONOMY AND SCOPE OF PRACTICE UNDER THE MIDWIFERY ACT, 1991}

As was noted earlier, a major objective of the Ontario legislation is to give professional autonomy to midwives. However, the legislation cannot achieve this purpose while the distinction between what constitutes a normal and an abnormal pregnancy or birth remain undetermined. The legislation also leaves uncertain whether the midwife has sole responsibility for determining the limits of normal within her statutory scope of practice.

The scope of practice and the authorized acts set out in the Act (ss. 3, 4) do not authorize an independent role for midwives in cases of abnormal childbirth conditions. The ability of a midwife to perform any of the controlled acts in a high-risk, abnormal delivery, for example, would depend on delegation by a physician under section 28 of the Act. A midwife who provided care independently in abnormal childbirth conditions would transgress the bounds of her scope of practice. Unless she were acting in collaboration with a physician, her actions or omission could be scrutinized under section $30(1)$ of the $R H P A$. Nothing in the new legislation directly prohibits a midwife, who is not performing a controlled act listed in section 27(2) of the RHPA, from stepping outside the bounds of her scope of practice and providing care to abnormal pregnancies, labour and deliveries. ${ }^{\text {oh }}$ However, her authority to provide care independently begins and ends with the definition of normal. Beyond the bounds described in sections 3 and 4, a midwife may become subject to liability under section 40 of the RHPA either for unauthorized performance of a controlled act or for unreasonable conduct under the general harm clause in section $30(1)$ of the RHPA.

The Midwifery Act does not define the meaning of normal pregnancy, labour and postpartum period. Yet section 3 of the Act does state that midwives, acting within the scope of their practice, provide care during a normal birth process. Similarly, the authority of midwives to perform the controlled act of managing labour and conducting deliveries is limited to "spontaneous normal vaginal deliveries" (s. 4 of the Midwifery Act).

The Midwifery Act grants midwives the authority to provide care to women during normal pregnancy, labour and postpartum period. To this end, qualified midwives may assess and monitor in order to "recognize the signs of abnormal situations which require a consultation or transfer of care to a physician." ${ }^{\text {th }}$ The Interim Regulatory Council on Midwifery (hereinafter IRCM), the AOM and, more recently, the Transitional Council of the College of Midwives, established in 1993, have taken steps to develop standards to detect deviation from normal pregnancy, labour and birth and to facilitate the transfer of care. Protocols listing such situations have been drafted by Ontario midwives and the IRCM and are being reviewed by the Transitional Council and representatives of the medical and nursing professions. "For example, during the antenatal period, inappropriate uterine growth requires a consultation, whereas frank vaginal bleeding requires a transfer 
of care. "6ix The IRCM's "Indications for Mandatory Consultation and Transfer of Care" outlines the risk factors. Depending on the severity of the condition, in certain circumstances consultation is required with either another midwife or a physician ("category I"). In "category 2," the listed circumstances warrant consultation with a physician. In "category 3 " transfer of care to a physician is required: ${ }^{\text {:9 }}$

The decision to consult with a family physician/general practitioner. obstctrician and/ or other specialist physician is the responsibility of the midwife. The severity of the condition and the availability of physicians will influence this decision. After consultation with a physician, primary care of the client either

a) is transferred to a physician or

b) continues with the midwife.

When primary care is transferred to a physician, the nidwife may provide supportive care within her scope of practice, at her discretion and with the agreement of the physician. The informed choice agreement between the midwile and client would outline the extent of midwifery carc.

In addition, to improve the safety and availability of home birth, the IRCM's Standards and Qualifications Committee has stipulated that all women requesting home birth be screened appropriately. According to a list of contraindications developed with other appropriate health providers. midwives will give their clients an outline of risks and benefits to enable the woman to make an informed decision about the planned place of birth. The IRCM's "Statement on Home Birth" offers the following advice:"11

In supporting and encouraging normal birh at home, the IRCM is nol advocating that all births take place at home. Undoubredly there are mothers and babies who will be safer in hospital and many mothers who will choose hospital birth. Available evidence does suggest that, for low-risk women, a planned birth at home with trained attendants is a safe and viable option.

Further advice in this matter is provided for midwives in the IRCM's document "Indications for Planned Place of Birth":"

When the midwife is providing primary care. she will support the woman's choice. after the client has carcfully considered the information and recommendations. Notwithstanding this, birth should be planned to take place in hospital in the circumstances of multiple birth. brecch presentation, preterm labor prior 10.37 weeks of pregnancy. and documented post-term pregnancy of more than 4.3 completed weeks. Other situations in which hospital birh should be planned would be assessed prenatally, with appropriate consultation as detailed in Indications for Mandatony Consultation and Transfer of Care.

Ihid.

Intcrim Regulatory Council on Midwifery (IRCM). Indications for Mandatory Consultation and Transfer of Carc. May 149I at I. The Transitional Council of the College of Midwives, appointed in 1993 with regulation-making authority, has approved mandatory consultation and transfer of carc guidelines based on those established by the IRCM.

IRCM, Statement on Home Birth, June 199I at I.

IRCM, Indications for Planned Place of Birth. January 1992 at 1. 
The medical profession has consistently opposed a return to the home birth option. ${ }^{72}$ A subcommittee of the Ontario Medical Association (hereinafter OMA) on the Implementation of Midwifery has recently indicated, however, that the OMA's opposition to home births is one of the remaining significant conflicts "where we may end up agreeing to disagree." ${ }^{73}$

Midwives also hope that legal recognition will both permit them to act as primary caregivers in normal births for women who choose hospitals and facilitate co-operation between midwives and the obstetrical support essential for safe out-of-hospital midwifery service. ${ }^{74}$ Midwives, their professional organizations and the IRCM have worked to define policy guidelines and standards for care and training. Without these efforts, the practice of midwifery risks being defined externally by structures and practices such as hospital procedures and obstetrical norms. The standards and guidelines developed by the IRCM reflect midwifery's traditional focus "on the healthy process of parturition and how to facilitate this process without upsetting nature's intricate balance." ${ }^{75}$

Helen McDonald, Midwifery Implementation Co-ordinator for the Ministry of Health, has described the task of defining "normal" for the purposes of midwifery's scope of practice as an "awful conundrum that has plagued people from time immemorial." anticipated the terms of section 3 of the Midwifery Act, "normal pregnancy, labour and delivery" will be articulated by a combination of IRCM standards such as the "Indications for Mandatory Consultation and Transfer of Care" and current clinical definitions.

Linda Bohnen, of the Ministry of Health, has stated that "midwives will define the difference between normal and abnormal in setting standards of practice. If there is a disagreement with other professions, opportunities exist for informal consultation by the governing bodies to work out differences of viewpoint. ${ }^{\text {"77 }}$ Examples of precedent-setting clinical definitions which could be the source of disputes as they are re-evaluated are the "Antenatal Record" form with an accompanying "Guide to Pregnancy Risk Grading," employed by health care providers under the authority of physicians. This list of risk factors associated with pregnancy and requiring either consultation with, or transfer to, a specialist obstetrician was drawn up by the Ministry of Health in conjunction with the OMA. An example of a pregnancy at no predictable risk (Grade $A$ ) is one with no significant medical disease or complication now or in the past. Under this risk-grading system, assessment of risk at each antenatal visit is an on-going question in the management of the pregnancy. There is always the possibility that "two or more minor risk problems can combine to produce a high risk pregnancy which may be categorized as requiring obstetrical care." ${ }^{78}$

P. Thompson. "The Home Birth Alternative" in C. Overall, ed., The Future of Human Reproduction (Toronto: Women's Press, 1989) 205 at 205.

K. Kaufman, "Implementation." supru note 67 at II.

V. Van Wagner, supra note 34 at 115.

E. Barrington, Midwifery is Catching (Turonto: NC Press, 1985) at 17.

McDonald Interview, supra note 49.

Interview with Linda Bohnen, Ministry of Health (1.3 March 1992) |hereinafter Bohnen Interview). Ontario Ministry of Health. "Guide to Pregnancy Risk Grading." 
The new regulatory system is designed to abolish the exclusive, monopolistic scopes of professional practice. Alan Burrows, Director of the Ministry of Health's Professional Relations Branch, has said that the framework is intended to eliminate hierarchy and inequality among existing and new professions such as medicine and midwifery. ${ }^{79}$ The Health Professions Legislation Review stated:"10

\begin{abstract}
It is important to note that under the new model. the authority to draw lines of demarcation between the professions' scopes of practice will, to a significant degree. shift away from the governing bodies of a small number of licensed professions. This authority will be more equally shared by all health professions, while the ultimatc authority will reside with the Government. The Health Professions Regulatory Advisory Council will provide a forum for discussion of these important scope of practice issues and a source of policy advice to the Minister.
\end{abstract}

In a departure from the existing system, physicians and midwives thus share authority and overlapping fields of practice in the provision of care in normal pregnancy and birth. The new regulatory approach seeks to promote equality in the relationships between health professions. The Ministry of Health contends that, within the new non-hierarchical mode, one profession such as medicine will not be in a position to monopolize a practice area or to constrain the scopes of practice of other professions. ${ }^{81}$

According to Linda Bohnen, the scope of practice statements do not themselves "have legal significance in terms of restricting people to certain areas of practice or of excluding others from areas of practice.... (I)n terms of who can do what, it is the controlled acts that you look at." ${ }^{\text {"2 }}$

\title{
C. ASSESSMENT AND DIAGNOSIS OF NORMAL AND ABNORMAL CONDITIONS
}

Under section 3 of the Medicine Act. 1991, the scope of medical practice has been defined as "the assessment of the physical or mental condition of an individual and the diagnosis, treatment and prevention of any disease, disorder or dysfunction. ".8. Physicians are authorized in section 4 of the Medicine Act to perform twelve of the thirteen categories of acts controlled under section 27 of the RHPA: all but those licensed to dentistry. ${ }^{84}$ In particular, physicians, including obstetricians and family/general practitioners, have the authority under section $4(11)$ of the Act to manage labour and

Interview with Alan Burrows, Ministry of Health (13 March 1992).

(miniking a New: Balance, supra note 46 at 16.

*I L. Bohnen. "In Defense of the Health Professions Legislation Review" (1989) 10 Health L. Can. 163 at 164-165. The College of Physicians and Surgeons of Ontario has opposed the ncw regulatory model: "The College belicves that the public would be better served if the exclusive scope of the practice of medicine were preserved," L. Bohnen. Ministry of Health. Debates, supra nole 23. No. S-9 at S-26) (6 August 1991).

n2 Debates, ibid. at S-254.

n. Medicine Acr. 1991. S.0. 1991, c. 30.

* $\quad$ Linda Bohnen has stated that: "Conceptually the way the health cure system has traditionally uperated is in imagining physicians do everything, that every other provider group just does a littlc bit.... For the first time. I think the legislation recognizes that physicians do not do everything. For example, they do not in tact supervise pharmacies... or fit and dispense dental prostheses." Debates, supra note 23. No. S-9 at S-260) (6 August 1991). 
conduct the delivery of either normal or abnormal births. Consequently, the scope of medical practice extends beyond the realm of normal and envelops that of midwifery. In contrast to midwives, physicians acting within their statutory scope of practice may diagnose and then treat any disease, disorder or dysfunction associated with childbirth care. In the words of section 3 of the Midwifery Act, midwives may "assess" and monitor women and their newborns and may also deliver care to women experiencing normal childbirth. The word "diagnosis" is omitted from their scope of practice. In addition, physicians are authorized in section 4(1) of the Medicine Act to follow a diagnosis with the communication of "a conclusion identifying the disease, disorder or dysfunction as the cause of the person's symptoms." Midwives, however, have not been granted the authority to perform this controlled act. It is prohibited under section $27(1)$ and section $27(2)(1)$ of the RHPA. In the area of childbirth health care, only physicians have independent authority under the new legislative scheme to: ${ }^{\text {s. }}$

communicat|c| 10 an individual or his or her personal representative a diagnosis identifying a disease or disorder as the cause of symploms of the individual in circumstances in which it is reasonably foreseeable that the individual or his or her representative will rely on the diagnosis.

Therefore, it can be argued that the legislative framework confines the sphere of practice and the authority of midwives to perform certain controlled acts within the paradigm of medicine. Both the statutory scope of practice and the list of authorized acts granted to midwifery are lesser subsets of authorized medical practice. It is possible that the hard won legal recognition under the Midwifery Act of midwives as specialists in normal birth may result in the implementation of midwifery as a subsidiary adjunct to medicine. In addition, the authority of midwives to provide care within their scope of practice could be conditional upon the definition of normal in a health care system dominated by medical diagnostic expertise and technical intervention.

If a pregnancy, labour or delivery is classed as normal, then medicine will share overlapping authority with midwifery. However, if a pregnancy disorder or high risk is diagnosed, then medicine can assert its exclusive authority over abnormal conditions in childbirth. Midwives thus may be fenced in by a narrow view of normal as determined by medicine's power to diagnose. The midwife's authority to treat autonomously lies within the realm of normal. The authority to define normal, however, lies in the exclusive diagnostic power of physicians to define abnormal, deviant disorders and diseases (section 4(1) of the Medicine Act).

It can be argued that midwives, although recognized by the law as experts in normal birth, do not have the authority to define the meaning of normal birth and therefore lack a truly autonomous scope of practice. The physician must first diagnose normalcy and a lack of complicating disorder in order that the midwife may perform activities within the scope of midwifery practice. As the representatives of the Toronto Birth Centre observed: "Until the past decade or so 'normal' also meant having your baby in a floodlit hospital 
delivery room." ${ }^{\text {"th }}$ Risk is ever-present throughout the birth process: "the act of diagnosis is not an end product it is not something you go to a particular professional for but rather it is part of a treatment process that is really quite inseparable. ${ }^{\text {"77 }}$ Thus, with the authority to diagnose deviations from normal, the physician can determine the availability and limitations of midwifery services at any point during the course of care.

Under the Medicine Act, physicians are experts in diagnosing and treating the abnormal human condition. Medicine has exclusive authority to communicate a diagnosis identifying conditions of disorder and disease which may pose a risk to the pregnant woman or to the fetus. Diagnosis is the core of medicine: "A physician's diagnostic skill is one of his or her most prized assets. " physician's diagnosis is "the very foundation of all therapy and is the single most important event which occurs in patient care." ${ }^{189}$

In the past, the medical profession obtained control over obstetrical care by promoting a view of pregnancy and birth as fundamentally abnormal. The dangers and risks of childbirth were exaggerated to advance the status and power of the medical profession.") The twentieth century "medicalization" of childbirth which contradicted and excluded midwifery care was based on the abnormalization of birth and on broad definitions of disorder and disease" necessitating medical intervention. Also its historically dominant position among health care providers has given the medical profession a measure of autonomy and privilege which will continue to be useful in struggles over autonomy and territory. ${ }^{92}$

In the past, as was described earlier, through formal training and the use of technology such as forceps, established medicine has undermined the practice of midwifery. Today, the new legislation reinforces and perpetuates medicine's claim to differentiate authoritatively and scientifically between normal and abnormal conditions in health care. Physicians retain sole territorial authority over the care of abnormal or "high-risk" pregnancy, labour and birth. In addition, the medical profession has the power to expand this exclusive domain over the abnormal by employing the power in RHPA, section $27(2)(1)$ to diagnose disorder, disease and deviations from the normal, thereby

nth Toronto Birth Centre. Submission w the Standing Committec on Socjal Developments Exhibit No. A $1 / 105 / 139$ (14 August 1991$)$ at 6.

n7 D. White, MPP (Durham Centre. N.D.P.). Delextes, supro note 23. No. S-10 at S-282 (7 August 1991).

xx C. Clappenon. M.D. F.C.F.P.. President of the Ontario College of Family Physicians, letter to the Clerk of the Standing Committee on Social Developnent. Exhibit No. A 1/05/097 (7 August 1991) at I.

ky Ontario Medical Assixciation. Submission to the Standing Committec on Social Development, Exhibit No. $A 1 / 05 / 314$ (26 August 1991) at 3.

'J) Donnison. Midwives and Medical Men (London: Heineman. 1977) at 38-39.

" P. O'Reilly. "Small "p" Politics: The Midwifery Example" in C. Overall. ed., supro notc 72.159 al 16.3.

"2 W. Amcy. Pomicr and the Profexsion of Ohstetrics (Chicago: University of Chicago Press, 1982) at 9. 
constraining the scope of midwifery practice. As Dr. Carole Guzman of the OMA has described the diagnostic process: ${ }^{33}$

|Flor a physician lit| includes the taking of the history and the physical examination. the forming of a list of possible causcs of the abnormality, the ability then to know the nature of these ideological factors and to choose from them what the most likely are and then to order the appropriatc tests."

Once the diagnosis is made by the physician, other health professionals may "carry on in their own spheres...."4t By limiting and defining what is normal and therefore within the independent practice of midwifery, this diagnostic power brings the pregnant woman and the fetus within the jurisdiction and preserve of medical care and hospital protocols.

Ivan Illich describes the influence of the physician's diagnostic power as follows:"5

Diagnosis always intensifies stress, detines incupacity, imposes inactivity and focuscs apprehension on non-recovery, on uncerainty, and on one's dependence upon future medical findings.... It also isolates a person in a special role, separates him from the normal and healthy, and requires submission to the authority of specialized personnel. Once a socicty organizes for a preventive disease hunt, it gives epidemic proportions to diagnosis.

It is this power to determine what midwives may do within their scope of practice which is inherently given to physicians in section $27(2)(1)$ of the RHPA. The client's status of health, whether normal or abnormal, low or high risk, will determine the authority of midwives to administer care. The question of whether a pregnancy, labour or delivery has deviated from the norm and is to be classed as a disorder or disease may be definitively answered by medical criteria.\%

Moreover, the issues of risk and normalcy linger throughout pregnancy, labour and delivery. For example. some hospital protocols set by physicians have placed arbitrary limits on "normal" sccond stage labour. In one case, the labour ceases to be normal after one hour and arguably is no longer within the authority of independent midwifery practice. ${ }^{97}$ Similarly, the rate of cacsarean deliveries in Ontario can be identified as part of the prevailing focus of obstetrics on the dangers of birth and the need for medical intervention. ${ }^{3 x}$ In 1985. prior to the Midwifery Act and the new legislation, the OMA estimated that approximately $85 \%$ of pregnancies could be categorized as posing no identifiable or significant risk, $12 \%$ had presented moderate level risk and $2-3 \%$ were high risk requiring specialized medical care." Normal status is thus the green light for independent midwifery care but there is a possibility of a constant change to a red light.

\footnotetext{
" Dr. C. Gutman. OMA, Debates, sitpra note 23. No. S-20) al S-65I (26 August 1991).

in Ibid.

"I. Illich. Limits Io Modicine (London: Marion Boyars. 1976) at 96.

Modicinc Act. 1991. s. 4(1); RHPA. ss. 27(1). 27(2).

$47 \quad$ Interview with A. Muranta (8 March 1992) |hereinafler Maranta Intervicu - 19921.

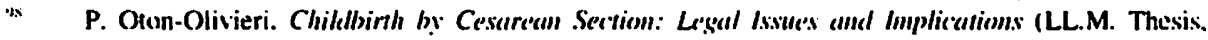
University of Toronto, 1990) at 67.

4. P. O'Reilly. supra note 91 al 170.
} 
Traditionally, midwives and physicians have diametrically opposed perceptions of the relation between normalcy and birth. Under the terms of section 3 of the Midwifery Act, the dominant concept of the birth process will determine the extent of the scope of midwifery practice. In the medicalized, hospital-based view of birth, pregnancy is, at all stages, potentially a pathological deviation from the normal or average state of a woman's body. ${ }^{\text {I(x) }}$ Childbirth requires close medical, diagnostic supervision, hospitalization and intervention if it is classed as a disease or disorder defined as "any deviation, obvious or latent, from what is believed to be the normal or average condition."

Under the new system, midwives are and will be qualified to assess and recognize deviations from the normal that require referral to medical staff for advice or treatment. However, medicine will control the identification and therefore the definition of deviations from normal under sections 3 and 4 of the Medicine Act. The new legislation therefore perpetuates a system in which "only doctors now 'know' what constitutes sickness, who is sick and what shall be done to the sick and to those whom they consider at a special risk...." 102 In this context, some physicians may take an excessively narrow view of what is normal. As a practising midwife, Anne Maranta has asked: "Are minor disorders and dysfunctions, such as vaginal infections, which do not in themselves endanger the life of the woman or the fetus, within the category of normal and therefore within the midwife's authority of care?"11!?

With the authority and "grant of confidence" IIM of sections 3 and 4 of the Medicine $A c t$, physicians excrcisc a unique kind of control over their own scope of practice and constrain that of midwifery. The exclusive authority to diagnose and to communicate a conclusion identifying disease. disorder and dysfunction has been given by statute to a profession which now, as in the past, occupies the pinnacle position within the health care hierarchy as the privileged gatekeepers of the system. The statutory power is added to the traditional dominance and entrenches medicine's authority to dictate the scope of midwives" practice and to restrict their responsibilities. This authority can be justified as the promotion of an optimally safe medical outcome of pregnancy. It can also invoke the uncertainty and risk inherent in pregnancy to expand the definitions of abnormal and risk so that no medical precaution is excessive. Women themselves are often taught to expect the normal to turn abnormal: ${ }^{\text {is }}$

F.P. 7uspan. M.D. writes: "the major issue in risk idemtification is 10 understand that pregnancy is not physiologic hut is a serious problem since it can produce death and increase the incidence of permanent damage to the survivors," Practical Manmel of Obsterrical Carre (St. I.ouis: The C.V. Mosby Company. 1982) al 54.

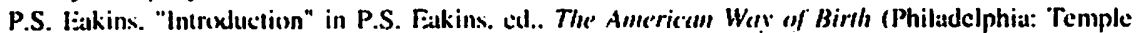
Univerily Press. (9)86) 3 all 7.

III: I. Illich. sumpra nolce 95 at +7.

I'i) Maranta Intervicu - 1992, suprou note 97.

10: I. Illich. supre nolic 9.5 it th.

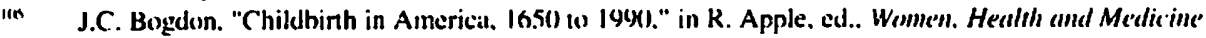
in America (New York: Garland Publishing. Inc.. 1990) 10)1 al 10.3 quoled in S. Sherwin. Feminism and Biesethic:s (Toronto: Faculty of Law. 1991) |unpublished) at 26. 
Women are encouraged to check constantly on the normality of their procreative system events onset of menstruation, birth control, pregnancy, ahortion and miscarriage, labor, childbirth post-partum conditions and so on.... We /women] are acutely aware that something might go wrong and typically fecl we need medical expertisc to assess normality and to accomplish care.

Trained to diagnose and to treat, physicians seek safety by diagnosing abnormality rather than health. ${ }^{116}$ In recent decades, obstetrics has developed technological diagnostic and monitoring tools which enhance the profession's ability to identify and contain "potential pathology." ${ }^{107}$ As William Arney has observed, obstetrical monitoring and surveillance of all births "deal with the problem of residual normalcy by ignoring it." "luk Autonomous midwifery practice may be negated under this "new regime of obstetrical control where no distinctions between normal and abnormal exist." ${ }^{109}$ Although these medical interventions have been developed and used to protect birthing women and their newborns, "many are now being employed unnecessarily as so called 'preventative measures' in cases of low risk pregnancy and childbirth." ${ }^{111}$

Midwives are, on the one hand, experts in normal birth and, on the other, are without the power to determine the bounds of their own expertise. As all pregnancies, labours and deliveries are uncertain and different, it is possible for physicians to claim that there is constantly a need to diagnose and that there is no right way to manage the inherent risk involved: "doctors can thus choose their preferred method of delivery (or treatment) invoking clinical experience as their guide (or exclusive authority to diagnose) and remain answerable to no one." ${ }^{\prime \prime \prime}$

The new legislation may produce a system which denies midwifery care to women on the basis of a narrow definition of "normal" and "low risk". As Maureen Baker has noted, "As long as physicians retain their current dominant role in the health care system, any changes to this system will come on physicians' terms."

The status of midwives as independent health care providers may depend on the prevailing view of birth set. not by midwifery standards, but by hospital and medical protocols. Currently, midwifery practice and hospital birth statistics are 'poles apart' on what is normal. As a midwife's client has noted: " $80 \%$ of 'normal' hospital births are accomplished with intervention, while $80 \%$ of midwife-assisted births happen without interference." ${ }^{\text {"1!3 }}$

Illich, supro note 95 at 92.

Ihid.

W. Arney, supra note 92 at 85.

lbid.

Ibid. all I80).

Manitoba Advisory Council on the Status of Women. Midwifeny: A Discussiom Paper (Winnipeg: Manitoba Advisory Council on the Status of Women. 1987) at 4.

M. Baker. suppra note 3 at 25.

A. Terpstra. Leller to the Standing Committee on Social Development, Exhibit No. N 1/05/297 (28 August 1991). 
Midwives have retained their position as specialists in their own right for normal births. but they are now to be integrated into a system in which the predominant medical view of pregnancy and birth is at odds with that of midwives. To past and current midwives, all pregnancies are normal until proven otherwise. For a midwife practising in a hospitalbased, physician-dominated system "(t)he reverse is now true, as all pregnancies now fall under medical management and are 'normal' only in retrospect." 114 Births are defined as abnormal (high-risk) or provisionally normal. The midwife's practice is thus what medicine defines as provisionally normal. An English midwife has observed that, by this logic, the midwife as an independent practitioner is defined out of existence. However she adds: ${ }^{115}$

Fortunately... | the practice of midwiferyl also embraces the vast areas of work which doctors either do not have the time for or do not see as imponant. Doctors are expensive and in a hurry but pregnancy and lahour are long. as is the real work of the midwifc.

In its study of various international midwifery regulations and practice, the Ontario Task Force on the Implementation of Midwifery observed certain trends in health care which undermined the ability of midwives to practice autonomously within their scope of practice. Among these trends are the definition of an increasing number of risk factors and a focus on physiological conditions related to risk as opposed to social and emotional factors. The diagnostic technology used to screen for abnormal risk has also increased the use of hospital-based care. The ability to label abnormal pregnancies has been replaced by an over-arching focus on identifying the risk of abnormality. ${ }^{116}$ In the final report of the Alberta Health Disciplines Board the same point is made. Referring to the midwifery pilot project carried out between January 1985 and February 1986 at the Misericordia Hospital, the representative of the College of Physicians and Surgeons stated that no risk scoring system for determining low and high risk pregnancies had yet been proven "adequate." Another representative added that about 15\% of pregnancies develop into high risk cases. They concluded from these points that physicians should therefore perform or oversee initial and intermittent assessments of women in the care of midwives and stay advised of the progress of their pregnancies and, therefore, be prepared to admit them into hospital if necessary. The College of Family Physicians spokesmen reiterated that physicians (in particular, family physicians or general practitioners) should function as "gatekeepers" to the health care system for childbearing women. ${ }^{17}$ Conflict between midwives and the established system of maternity care over the definition of normal will affect the ability of midwives to import the essential normalizing qualities of midwifery into hospitals. A midwife attending birth either in a hospital or at home who does not act in accord with accepted hospital or medical standards for normalcy and the level of lowrisk may be viewed as overstepping her scope of practice and face penalties. ${ }^{118}$ Health Care (New York: John Wiley and Sons, 1986) 35 at 37. lhid.

Ontario Tusk Force Report. supra note 6 at 62. Alberta Health Disciplines Board Report, supra note 8 at 54. RHPA, ss. 27(1), 30(1). 
A supporter of midwifery has questioned the implications of limiting independent midwifery practice to designated "normal childbearing": "'"

If midwives reject arbitrary hospital definitions of risk and normalcy in favour of a more reasoned approach dependent upon the condition of the woman and fetus in labour. whose definition wins out when a woman chooses to deliver in hospital with a woman attending? Will midwifery's vicw of normalcy apply only to planned home birth? Will midwives have 10 'give over' the labour woman to the hospital protocol?

\section{ASSESSMENT WITHIN MIDWIFERY'S SCOPE OF PRACTICE}

Under section 3 of the Midwifery Act, the practice of midwifery includes assessments of "any women during pregnancy, labour and the post-partum period and of their newborn babies." Consequently, according to the terms of the Act, the authority of midwives to assess is not restricted to normal conditions. They may, however, provide care only to women experiencing normal pregnancy and birth. As was argued above, what is a normal pregnancy, labour or delivery is ultimately to be determined by the physician's diagnosis of abnormal. Midwives, however, will be trained and expected to assess their clients in order to detect deviations from the norm which require referral to a physician for diagnosis. ${ }^{120}$

While a midwife may assess her client's condition, she is not authorized to communicate to the client "a diagnosis identifying a disease or disorder as the cause of symptoms." 121 The new legislation does not contain definitions of the terms "assessment" and "diagnosis" or of "disease" and "disorder." In 1991, Frances Lankin, then Ontario's Minister of Health, has indicated how difficult this issue is to resolve: ${ }^{122}$

The line between what is assessment and what is a diagnosis and what is communicating assessment and communicating diagnosis has become very controversial and is one where we have not at this point in time been able to develop language that mects everybody's concerns. ${ }^{\text {'. }}$

On the counter side of that, if you were to climinate it altugether, you would find members of these regulated professions who are authorized to perform that controlled act feeling that there would be great danger to the public and to public safety.

A. Terpstra, supra note 113.

IRCM. Laboratory Testing and Diagnostic Imagery. May 1991.

RHPA. s. 27(2)(1).

F. Lankin. then Ontario Minister of Health. Debates. supra note 23, No. S-9 at S-239 16 August 1991). Diagnosis within scope of practice has heen recognized as an authorized act for a limited number of professionals: Medicine. Chiropractice, Dentistry. Psychology, Optometry, and Chiropody. In contrast, Speech Pathologists may assess and treat speech disorders but have not been recognized as diagnostic practitioners (Audiology and Speech Language Pathelogg. Act. 1991, S.0. 1991 c. 30. s. $3(2))$.

For example, the Ontario Nurses Association made a submission to the Ministry of Health requesting recognition of "nursing diagnosis," Submission to the Standing Committee on Social Development. Exhibil No. A 1/05/053 at 39-40 (7 August 1991). 
The aim of the legislation thus, is to prevent unqualified practitioners from making diagnoses upon which people will rely. At the same time, the legislation does not seek to prevent or inhibit midwives and other non-diagnosing health professionals from making and communicating assessments as described in the statutory scope of practice. ${ }^{124}$ Also, subsection 29(2) of the RHPA states that:

\footnotetext{
Subsection 27(1) dexs not apply with respect to a communication made in the course of counselling about emotional, social. educational or spiritual matters as long as it is not a communication that a health profession Act authorizes members lo make.
}

Linda Bohnen has said that notwithstanding the prohibition on performing the controlled act of communicating a diagnosis, midwives are not restricted in their ability to communicatc the results of an assessment. Subsection $27(2)(1)$ of the RHPA leaves a lot of room for communication by a midwife. ${ }^{125}$

In addition, although there are no statutory definitions of assessment and diagnosis, each, according to Linda Bohnen, is a distinct function with a clear, independent meaning. In her view, assessment is the "measure of the health of a patient using the norm as a reference point," whereas the concept of diagnosis in section $27(2)(1)$ refers to a conclusive statement in medical terms. ${ }^{136}$ Nevertheless, the new legislation does not clarify this distinction between diagnosis and assessment.

Since the scope of midwifery care centres on normalcy and not disorder or disease, the question of diagnosis is only "peripherally relevant to midwifery." ${ }^{27}$ Midwives are free to practice, referring clients to physicians for an authoritative. diagnostic conclusion.

Yet, the lack of a clear distinction between the communication of an assessment and the prohibited communication of a diagnosis leaves midwives in an uncertain position. At what point does an assessment cross a line and become an authorized diagnosis? If a midwife informs a client of an assessment which is later judged "incorrect," can she be held accountable under section 27(1) of the RHPA for the communication of a diagnosis? Does the midwife's capacity to provide care independently to normal or "low-risk" pregnant women encompass the assessment and treatment of certain minor disorders which could conceivably be within a normal range of conditions? If so, how are midwives to confine their thoughts and statements to "assessment" without a clear statutory definition of unauthorized communication of diagnosis?

This ambiguity may inhibit meaningful interaction between a midwife and her client. A midwife who is convicted of contravening subsections $27(1)$ and $27(2)$ is guilty of an offence and may face a fine of $\$ 25,000$ and/or imprisonment of up to six months. Conviction would be based on the unauthorized performance of a controlled act and would not require proof of incompetence or harm caused.

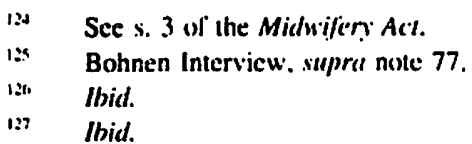


The legislation is not intended to limit the ability to make an assessment, yet it contains no definition of "assessment." The legislation does, however, prohibit unauthorized communication to an individual of a diagnosis but here, again, no definition of "diagnosis" is given. Physicians control the dominant form of knowledge, diagnosis, which implies a "deskilling" of other health professionals "insofar as their need or medical legitimacy will lead them to acquiesce in a re-definition of their role." ${ }^{\text {12k }}$

In essence, midwives who may assess, but not diagnose, occupy a lesser position within the legislated hierarchy of professional knowledge. To defend herself against potential liability, a midwife's assessment of a client's condition should be accompanied by a statement of the need for an authoritative diagnosis confirming the presence or lack of abnormality.

Responding to these concerns, Alan Schwartz. of the Health Professions Legislative Review, has stated that "the system will work" because health professionals will not be stopped from communicating assessment results "that they are communicating every day. "22) He also predicted that "the system is not perfect... and there will be glitches. The glitches will fix themselves." ${ }^{13.1}$ In cases of dispute over the meaning of assessment and diagnosis, courts will apply common sense to interpret the limits on communication under section 27(2)(1). In Alan Schwartz's opinion: ${ }^{131}$

When it comes to it. the courts, as they almost always do, will come to a commonsense meaning within the parameters of this entire bit of legislation. understanding how health care is delivered and give a definition for 'diagnosis" that will suit a particular case in a meaningful way.

\section{E. THE AUTHORITY OF MIDWIVES TO COMMUNICATE}

The prohibition in section 27 of the RHPA focuses not on the diagnostic process but on the communication of a diagnosis. The controlled act is not, in subsection 27(2)(1). diagnosis itself, but a form of communication identifying a disease or disorder as the cause of the individual's symptoms in "circumstances where it is reasonably foreseeable that the individual or his or her personal representative will rely on the diagnosis." ${ }^{132}$ Communication of a diagnosis or "conclusion identifying a disease or disorder or dysfunction" 1.33 is omitted from the list of acts which a midwife is authorized to perform while practising midwifery. ${ }^{1.44}$

It is unclear how broad an interpretation may be given to the act of communication. The intention of the legislation is to protect the public and prevent reliance on diagnoses

G.V. Larkin. "Medical Dominance and Control: Radiographers in the Division of Labour" (1978) 26 Sociological Review 843 at 8.52 in R. DeVries, Regulating Birth: Midwives. Medicine and the Law (Philadelphia: Temple University Press. 1985) at 15 |hereinafter Reguluting Birth|.

A. Schwart7. Debultes, supra note 23. No. S-24 at S-784 (16 September 1991).

Ihid. at S-782.

Ibid. at S-780.

RHPA, s. 27(2)(1).

Medicine Act. 1991. s. 4(1).

Midwifen. Act. 1991. s. 4. 
made by unqualified practitioners. Significantly, in submissions to the government, midwives and their representatives did not seek the inclusion of diagnostic activity in the scope of midwifery practicc. ${ }^{135}$ In the end, the legislation does not prevent a midwife from making her own diagnosis, but the RHPA, section $27(1)$, does bar her from "communicating a diagnosis" without delegated authority of a diagnostic practitioner in accord with section 28 of the RHPA.

It is possible that this restriction on unauthorized "communication" could prevent or inhibit a midwife from communicating independently with her client concerning a "diagnosis" made by a physician for that client. Would a midwife who provided, without delegation (by a physician) under section 28. alternative or supplementary health care information regarding a physician's initial diagnosis, contravene section $27(1)$ ? The physician's authority over communication of diagnosis in subsection $27(2)$ (1) of the RHPA exists in the context of "a culture where scientific expertise regularly licenses authoritarian power and where experiential, subjective knowledge tends to be readily dismissed....."13n Physicians control the information required for much of the difficult decision-making in health care: ${ }^{1.77}$

Medicine not only rellects the wide consensus that scientific expertise must be relied on to detect ills (and illnesses) but it actively fosters attitudes of deferential respect to its own particular form of knowledge and training in soxicty which undermines women's claims to other forms of knowledge and authority.

In a recent article concerning communication of diagnosis entitied "How to Get Your Patients to Really Hear You." Dr. Patricia L. Elliott began nostalgically: ${ }^{138}$

In the good old days of my fantasics. physicians didn't burden patients with elaborate explanations of their diagnoses. Putients revered the doctor and accepted his instructions as holy writ. He squeezed a hand, a shoulder and left behind an evil tasting tincture, then departed lor the next call confident that his advice would he followed to the letter.

Today, however, "we all have patients who seem to sabotage communication at every turn. There's a whole arsenal of ways in which a patient can deny his disorders and misconstrue his doctor's findings." ${ }^{\text {13\% }}$

Sec IRCM. Submission io the Standing Committee on Social Development, Exhibit No. N 1/(05/1.38 (4 August 1991): Association of Ontario Midwives. Submission to the Standing Committee on Social Development. Exhibit No. N 1/05/058A (16 August 1991). By contrast, members of the professions of Nursing and Speech Pathology unsuccessfully sought recognition us diagnostic practitioners. See Ontario Nurses Association. Submission to the Standing Committec on Social Development, Exhibit No. A $1 /(15 / 053$ and P.A. Square. Ph.D.. Chair. Graduate Department of Speech Pathology. University of Toronto. Presentation to the Standing Committec on Social Development. Exhibit No. A 1/05/112 (12 August 1991).

S. Sherwin. Feminism and Biocethics, supra note 105 at 17.

Ibid.

P.L. Elliont. M.D.. "How to Get Your Patients to Really Hear You" (1992) Mar. 16 Family Practice, 45 al 46.

Ibid. 
Elizabeth Nihell, an eighteenth century English midwife, protested contemporary medicine's domineering use of scientific information. Child-bearing women were: ${ }^{141}$

in some meusure victims of that scicntific jurgon, employed to throw dust in their eyes and to blind them to their danger or perdition! May they, in short. see through thal cloud of hard words used by pedants. whose interest it is to impose themselves upon them....

Today, an Ontario midwife has observed that "part of midwifery is trying to make sense of the morass of technological wizardry... and to help patients not to react blindly against technology but to use that technology when it's needed." ${ }^{|t|}$

In communicating with their clients, midwives place women at the centre of reproductive decision-making. From this perspective, women are the experts of their own experiences. Therefore, the chief advocate for the fetus or newborn is the pregnant woman, not the attendant health care provider.

Midwives seek to employ a non-hierarchical means of sharing knowledge based on the client's right to not simply informed consent, but to informed choice. ${ }^{142}$ Under the "Philosophy of Midwifery Care in Ontario": 143

Midwives promote decision-making as a shared responsibility, between the woman, her family (as defincd by the woman). and her care givers. The mother is recognized as the primary decision maker.

Medical control over diagnostic techniques and information excludes alternative, unorthodox voices valuable to the health care consumers. It will inevitably shape the view and treatment of pregnancy and pregnant women. ${ }^{14 t}$ Control over communication of diagnosis in pregnancy, labour and delivery entails considerable influence over the course of treatment and the choice of how the care will proceed. A concentration of the power to channel all-important diagnostic information to women may adversely affect a woman's right to make a truly informed decision about giving birth "with the professional of her choice, in the setting of her choice, and in the manner of her choice." 145 This type of professional authority over knowledge would contribute to a position of supremacy within a hierarchy of health care providers and patients. Control by a health profession over the communication of diagnosis means control over the terms by which health care decisions are made. ${ }^{146}$

W. Arncy. supra nole 92 al 31.

Quoted in Ontario Midwifery Task Force, Submission to the Standing Committce on S(xcial Development, Appendix 2, Exhibit Nu. N 1/05/207 at 6 (19 August 1991).

Maranta Intervicw - 1992. supra note 97.

IRCM. Philosophy of Midwifery Care. January 1992.

A. Lippman, "Prenatial Diagnosis: Reproductive Choice? Reproductive Control'?" in C. Overall, ed.. supra note 72. at 182.

Toronto Women's Health Network, Submission to the Ontario Task Force on the Implementation of Midwifery, in Omarios Task Force Repurt. supru note 6 at 259.

Quoted in W. Arney, supra note 92 at 237. 


\begin{abstract}
Women...provide the data which are subjected to analysis only to come back and haunt women in the guise of scientifically known distributions of possible experiences. Women are offered the "free choice" of moving themselves to the apex of scientifically known distributions of experience to uptimize their experience of childbirth. But this is not choice. The woman's lask becomes not the human task of assessing of her own experience but the scientific lask of locating herself in terms of deviations on normalizing distributions and participating in exercises, lechniques, and rituals to correct and optimize her situation.
\end{abstract}

Many women who have had a caesarean section have expressed dissatisfaction with hospital approaches to decision-making and communication. ${ }^{137}$ The current system of reproductive care has been viewed as denying women real choices in childbirth by failing to provide adequate and varied information about viable options. ${ }^{14}$ On the one hand, the absence of alternative sources of information for comparison and evaluation may adversely affect a woman's experience in childbirth. On the other, if a woman does not accept the information presented, she may be considered an irresponsible childbearer and mother. Critics have observed: "Doctors have been using their self-appointed role as guardians of fetal interests to justify increasing obstetrical intervention. "149 If a physician communicates a diagnosis of prenatal disorder to a woman and recommends certain tests or procedures, does the woman have a real choice? One woman described this situation in a personal way when she wrote to the Task Force on the Implementation of Midwifery. in Ontario as follows: ${ }^{\mid(5)}$

To make a long story shorr, it all ended in a cacsarean section which I felt and still fecl was unnecessary. The decision was the doctor's. It was a decision we were forced into accepting. We werc very vulnerable and feel that he used unnecessary scare tactics. If we had been educated on casesarean prevention or warned of the risks of interventions administered throughout my short labour, we would have been belter prepared to refuse the intervention and to battle off insistent nurses and doctors.

The decision to legalize midwifery in Ontario as an autonomous women-centred profession was. in part. due to the recognition that orthodox medicine and society in general had systematically undervalued the female perspective and undermined women's integrity in the birth process. ${ }^{151}$ However this rationale has been undercut by the monopoly on communication of a diagnosis reserved to medicine in the new legislation. This new model sanctions medicine's considerable authority in diagnostic decisions and its dominance in the hierarchy of health professionals.

The physician's control over communication may silence the voice of midwifery and is a continuation of a tradition of decisions in the legislature and the courts based on confidence in the paramount importance of medical expertise derived from diagnostic

Ontarien Task fierce Report. supra note 6 at 264.

Ibid. at 81.

V. Van Wagner \& B. Lec. "Principles into Practice: An Activist Vision of Feminist Reproductive Health Carc" in C. Overall, cd.. supro note 72. 238 al 254.

Ontarion Task Force Report. supra nute 6 at 264.

Ibid. at 25. 
technology. ${ }^{152}$ Subsection $27(2)(1)$ of the RHPA arises from historical relationships within the health care system which, while still influential, are no longer suitable to a scheme intended to enhance simultaneously safe choices and quality in health care by increased dissemination of, and access to, knowledge and information.

\section{F. THE RELATIONSHIP BETWEEN LIABILITY UNDER SECTION 30 OF THE RHPA AND ACTING OUTSIDE THE SCOPE OF MIDWIFERY PRACTICE}

Section 30 of the RHPA is intended to be an "important safety net" for the public. ${ }^{153}$ The list of controlled acts in section 27(2), however carefully drafted, might not encompass all harmful health care activity and might not keep pace with newly developed hazardous technologies or procedures. ${ }^{1.4}$ Therefore, the "basket" or "harm" clause in section 30(1) was included in the new legislation to address the potential of harm resulting from treatment or advice provided by persons who are not members of a regulated health profession or who, if they are members, exceed their scope of practice or authority to act. The inclusion of a harm clause has been the subject of considerable debate since the mid1980 s and the work of the Health Professions Legislation Review. The list of controlled acts was described by the College of Physicians and Surgeons as unconnected fence posts which would not sufficiently restrain unqualified health practitioners whether regulated or not. Recounting the history of the legislative review and the inclusion of a harm clause in the draft legislation, Linda Bohnen commented: ${ }^{155}$

The harm clause was proposed as the wire on the fence. To be fair, I think there was also a strong desire to persuade the College of Physicians that the new licensed act model was enforceable and was in the public interest and the hope was that the harm clause would persuade them to support the model. That really did not happen.

However, in response to criticism of the utility and wording of the harm clause, it was omitted when the present Ontario government retabled the legislation on April 2, 1991. In the view of the Ministry of Health, the controlled acts and the prohibition in section 27 of the RHPA provide ample public protection, while a general clause might have an undue effect on health care practice. ${ }^{150}$ Nevertheless, following hearings before the Standing Committee on Social Development, a harm clause was reinserted in the RHPA and the Act was given Royal Assent in November 1991. Section 30 provides that a midwife, acting outside the profession's scope of practice and without the direction or delegated authority of a physician, shall not:

1:2 R. De Vries, Reguluting Birth, supra note 128 at $11-12$.

(5) A. Schwarty, Debates, supra note 23, No. S-24 at S-780 (16 September 1991).

19 L. Bohnen, Dehalles, supra note 23, No. S-10 at S-284 (7 August 1991).

is Mid. at S-285.

14. L. Buhnen. Debutes, supra note 23. No. S-9 at S-245 (6 August 1991) and No. S-10) at S-284 17 Augus 19911. 
treat or advise a person with respect to his or her health in circumstances in which it is reasonably foreseeable that serious physical harm may result from the treatment or advice or from an omission from them.

The new regulatory model relies on the governing colleges, not police or crown attorneys, to assume primary responsibility for investigating and prosecuting violations in relation to scope and practice and the controlled acts licensed to the respective professions. It is expected that the Colleges are capable of judicious exercise of their authority and will put the public interest before professional interest. ${ }^{1.7}$ One of the objects of a College and its Complaints and Discipline Committees is to "regulate the practice of the profession and to govern the members in accordance with the Health Profession Act..., the Regulated Health Professions Code and the Regulated Health Professions Act. 1991 and the regulations and by-laws." ${ }^{15 K}$ In the report of the Health Professions Legislation Review, further clarification is given: "where two or more professions share a licensed act, it would be sensible for their governing bodies to co-operate in the prosecution." ${ }^{159}$

Linda Bohnen has stated that, under the Health Disciplines Act, generally the Colleges only prosecuted, on a complaint basis, those cases where the potential hazard happened to violate one of their exclusive scopes of practice. ${ }^{1(x)}$ it is possible that a College's decision to prosecute under section 27(1) and section 30 of the RHPA will continue to be complaints-based and within the discretionary power of a College's councili: ${ }^{|6|}$

We are not talking about this becoming a provincial oftence being prosecuted with the frequency of the Highway Traffic Act. That is not how it works. We do not have health police like the OPP patrolling these things and we do not want them....

The College of Midwives also has the statutory object of developing, establishing and maintaining standards of practice and a code of ethics to assure the quality of the practice of midwifery. ${ }^{162}$ In addition, under section 95(1) of the Regulated Health Professions Code, 1991, the Council of the College may make regulations defining professional misconduct, prescribing standards of practice and prohibiting members from acting beyond the profession's scope of practice. The Code prescribes, in sections 25 and 26, that complaints of professional misconduct by a midwife are filed with the College's Registrar, investigated by the Complaints Committee and heard by a panel of the Discipline Committee. A panel shall find that a midwife has committed an act of professional misconduct if, for example, she has been found guilty of an offence relevant to her suitability to practice or has breached the standards as defined in the regulations. ${ }^{16.3}$

L. Bohnen, "In Defence of the Health Professions Legislation Review," supra note 81 at 167. Reguluted Health Professions: Codle. 1991, (being Schedule II of the RHPA, supra note 2) s. 3(1)I Ihereinafier Regulated Health Professions Crode].

Striking a New Balance. supra note 46 at 110.

1. Bohnen. Debatess, supra note 23. No. S-10 at S-28.5 (7 August 1991).

Ibid.

Regulated Health Professions Code, ss. 3, 4, 5.

lbid. s. 5 I(1). 
A member of the College may be subjected to professional misconduct investigative and disciplinary proceedings for failing to meet the standards, skills, ethics and continuing competence of the profession. ${ }^{104}$ On another ground, distinct from alleged incompetence, the College could also undertake to discipline a midwife who treated or advised outside her statutory scope of practice, for committing an offence under section $27(1)$ in the case of a controlled act or, more generally under section $30(1)$ where the risk of serious physical harm is "reasonably foreseeable."

Subsection 30(1) will only apply to the conduct of a midwife acting on her own responsibility outside the scope of midwifery practice as described in sections 3 and 4 of the Midwifery Act. Therefore, when a violation of section $30(1)$ is alleged, a possible defense is to establish that the midwife was operating within her scope of practice. The issue may be whether she stepped over the bounds of "monitoring" and "assessing" to engage in diagnostic activity. Also, the meaning of "normal" pregnancy, labour, or delivery will determine whether the midwife provided care, (treatment or advice), outside her statutory scope of practice. Would a midwife who provided care to a woman subsequently diagnosed by a physician as abnormal, be regarded as acting outside her scope of practice? If a delivery attended by a midwife acting on her own authority has an undesirable outcome, has that midwife acted outside her scope of practice and is she therefore subject to scrutiny under section $30(1)$ ?

A physician acting in the same circumstances is much less likely to be found to have advised or treated outside medicine's scope of practice and therefore to be subject to section 30(1). The broad-ranging description in section 3 of the Medicine Act of medicine's scope of practice incorporates abnormal and normal childbirth conditions. This sweeping concept of the practice of medicine means that a physician is virtually at all times, "a member treating or advising within the scope of practice of his or her profession"165 and therefore immune from the application of section 30(1). Similarly, as physicians are authorized to perform within their scope of practice virtually all controlled acts listed in section $27(2)$, it is unlikely that a physician could contravene either section $27(1)$ or section $30(1)$.

However, one of the statutory objects of a College, such as the College of Physicians and Surgeons, is to "regulate the practice of the profession" and to "administer" the new legislation "as it relates to the profession." ${ }^{160}$ For example, physicians have been granted in the RHPA unequivocal authority to manage labour or conduct the delivery of a baby. The authority of midwives in contrast, is limited to cases of spontaneous normal, vaginal deliveries. ${ }^{167}$ In most circumstances, a midwife who transgressed the bounds of her statutory authority would have entered the domain of medicine. Consequently, the College of Physicians and Surgeons of Ontario (CPSO) has the discretionary authority to bring action under section $27(1)$ and section 30(1) against midwives in matters concerning the scope and the licensed acts of the practice of medicine. Moreover, section 87 of the Code

Ibid. ss. 25. 26.

RHPA, s. 30(1).

Regulated Health Professions. Code. s. 3.

Midwijery Act, ss. 3. 4. 
authorizes a College to apply to a court for an injunction directing a person, including non-members of that College, to comply with a provision of the health professions legislation and regulations.

A midwife's immunity under the terms of section $30(1)$ is limited to the "normal" status of her client's pregnancy. If something goes wrong with the pregnancy, could the pregnancy be viewed, in hindsight, to have been normal or abnormal? The prevailing definition of when a pregnancy, labour or delivery deviates from the norm will determine where the scope of midwifery practice ends and where section 30(1) begins. Expert testimony will be sought to define the limits of what is "normal." In a dispute, a physician's diagnosis of abnormality will likely prevail over a midwife's assessment of normality. Under the new legislation, it is the physician, not the midwife, who is the expert in defining deviations from the norm and from the scope of midwifery practice.

Once a midwife is found to have exceeded her scope of practice, section 30(1) does not focus on whether actual harm was caused but rather on the risk of harm and whether it is reasonably foreseeable that serious physical harm may result. It is arguable that a midwife who provides care outside her scope of practice without the direction of a physician is ipso facto acting unreasonably in high risk circumstances and in violation of section 30(1). This section of the RHPA will serve to police the scope of practice of midwifery and limit autonomous action by midwives to an area defined according to the medical model of birth.

\section{THE IMPLEMENTATION OF THE MIDWIFERY ACT}

The Midwifery Act and the Health Professions Acts received Royal Assent on November 25. 1991. Certain sections of the RHPA and section 12 of the Midwifery Act are currently in force. It is expected that the remainder of the RPHA and Midwifery Act will be proclaimed into force by the end of 1993 when the regulations necessary for the new scheme have been formulated. ${ }^{16 x}$

\section{A. THE RELATIONSHIP BETWEEN MIDWIVES AND OTHER HEALTH PROFESSIONALS}

Successful implementation of the Midwifery Act depends upon the development of a collaborative environment for health care professionals, government and the public. ${ }^{169}$ Consequently, midwifery organizations, the Interim Regulatory Council on Midwifery (IRCM), and subsequently, the Transitional Council of the College of Midwives, have undertaken various interprofessional and public education activities throughout the province. Prior to the implementation of regulated midwifery practice, a "phase-in" preparatory period of approximately two years is required ${ }^{173}$ to establish standards and

im Elinor Caplan. Chair of the Standing Committee on Social Development. Debates, supra note 23. No. S-19 at S-590 (22 August 1991). 
policies for the profession, certification and education programs, and self-governance procedures which will embody the ethics underlying midwifery practice. Midwives are working on these matters in consultation with other professionals, consumers and institutions. Mary Eberts, a lawyer and chair of the IRCM has stated: "The more we share with them, the more the way to fruitful collaboration opens before us." ${ }^{171}$

The Ontario government announced on October 15, 1991 that the province will establish a Bachelor's degree program in midwifery. The program is expected to be ready to enrol students in the 1993-94 academic year. ${ }^{172}$ In addition, a one-time preregistration program was offered in September, 1992 at Toronto's Michener Institute in order to assess the skills of experienced Ontario midwives prior to their registration by the College and integration into the health care system.

The regulatory distribution of controlled acts and scopes of practice provisions among numerous health care professionals necessitates the development of co-operative collegial relationships based on good faith and established protocols. The IRCM has stated: ${ }^{173}$

Whilc we recognize that, for some of these professions, the entry of a new primary care giver will requirc adjustment of traditional expectations and familiar working structures, we are confident that the midwife will soon become a valued member of the health care system all over Ontario as she already has in some communities and settings.

The passage of the Midwifery Act serves to close debate on whether midwifery ought to be recognized by the government as part of Ontario's health care system. The focus shifts to issues and attitudes surrounding the implementation of midwifery services. Having passed the new regulatory legislation, the government anticipates that "resistance to the introduction of midwifery will be minimal."174 At present, the government itself does not intend to establish or fund directly any "awareness" programs designed to address any lingering inter-professional "turf issues." 175 It will be the task of self-governing midwives and their supporters to advocate the value of midwifery services to Ontario's health care system. As the new regulatory structure matures, "eventually the word does get around." 176

In particular, midwives need good professional relations with physicians if they are to practice effectively. ${ }^{177}$ As the Ontario Task Force on the Implementation of Midwifery observed: "[f]or midwifery to be safe and effective, physicians must be willing to consult with midwives and receive referrals from them. ${ }^{178}$ In recent years, attitudes among

M. Eherts, "Statement of the Chair" (March 1991) 2:1 IRC Gazelle 8. IRCM. "Ontario Ministers Announce New Degree Program for Midwilery" (199I) 2:2 IRC Guzette I.

IRCM. Submission to the Standing Committee on S(xial Development, Exhibit No. N 1/05/138 at 10 (14 August 1991).

Burrows Interview, supra note 79.

Ihid.

Ihid.

E. Barrington. Midwifery is Catching. supra note 75 at 40.

Ontario Task Force Report, supra note 6 at 62. 
physicians toward midwifery have begun to "soften." 174 In the opinion of Anne Maranta, a Kingston area midwife, while a growing number of obstetricians and general practitioners are willing to co-exist with professional midwifery, some practising midwives continue to encounter, despite the passage of new legislation, an unyielding "brick wall" on the part of medical practitioners in some communities. ${ }^{1 \text { to }}$ Anne Maranta has also remarked: "You can't legislate physicians' attitudinal changes. You can put the policy in place but the attitudinal changes are going to take a lot of time to work on." ${ }^{181}$ Ideally, under the new legislation, midwives and physicians will practice as equal participants in an improved maternity care system incorporating both obstetrics and midwifery, making appropriate use of each according to the type of pregnancy and the wishes of the client.

To this end, the OMA set up its sub-committee on the Implementation of Midwifery. Its mandate was to help facilitate the integration of midwifery and to "identify policies that will foster a climate of mutual respect between midwives, physicians and institutions." ${ }^{1 \times 2}$ Respect and credibility for midwifery, critical for individual working relationships... are expected to come with time as midwives and physicians collaborate under the new regulatory framework. ${ }^{1{ }^{3} 3}$ Notwithstanding the legal recognition of midwifery, the establishment of collegial relationships will not be easy. As one midwifery supporter has observed: ${ }^{1+1}$

If you choose to have a midwife attend your birth. I guess it is still going to come down to your having to connect with either a family physician or an obstetrician who is willing to support that choice and allow you to do that. That is probably going to continue for two or threc ycars.

\section{B. THE LOCATION OF THE PRACTICE OF MIDWIFERY}

The professions of midwifery and medicine continue to disagree radically on the question of planned home births and the availability of medical support services. ${ }^{185}$ To Ontario midwives. planned home birth is an integral part of autonomous midwifery practice and a safe alternative for selected low-risk pregnancies. ${ }^{18 t}$ On the other hand. Dr André Lalonde, executive vice-president of the Society of Obstetricians and Gynaecologists of Canada has observed: "You don't find one percent of the doctors willing to do home birth even though they could do it. That's got to tell you something." ${ }^{117}$ In support of this view, David Peachey of the OMA has said: "We support the integration of midwives into the hospital process but we just can't support

McDonald Intervicw. supro note 49.

Maranla Intcrview - 1992, supra note 97.

Ibid.

Staff. "OMA Sub-Committec Aids Midwifery Integration" (November 1991 ) Ontario Medical Review" 10 at II thercinafier OMA Sub-Committcel.

Interview with John Krauser. OMA Health Policy Department (16 March 1992); Burrows Intervicw. supra note 79.

Louisc Carrisll. Debates, supra note 23. No. S-19 at S-591 (22 August 1991).

OMA Sub-Committce. supra notc 182 at 11.

Onturio Task Force Reporl, supra note 6 at I(x); IRCM. Statement on Home Birth. June 1991.

Quoted in C. Thumpson. "Natives Oppose Midwite Regulations" (University of Toronto) Varsit!. Newis (7 November 1991) 3 at 3. 
home births because of the inability of midwives to identify either fetal or maternal complications." ${ }^{\text {"\$x }}$

An independent report, recently commissioned by Alberta's Health Discipline Board, concluded that with proper safeguards home birth is a safe option for carefully screened, properly attended women. ${ }^{\text {ky }}$ However, according to the Minister of Health's Midwifery Implementation Co-ordinator, Helen McDonald, the Ontario government does not plan to treat home births as a legislative issue. ${ }^{190}$ The new legislation neither bans nor permits home birth. Above all, planned home births are likely to continue in Ontario regardless of the prevailing view of established health professionals. Therefore, it is imperative that reciprocal standards of practice and arrangements be set in order for midwives to attend home births with the assurance of obstetrical support when needed.

The IRCM expects that midwifery practice will occur in hospitals, hospital birth centres, independent birth centres, community health clinics and homes. ${ }^{191}$ The provincial funding mechanism for midwifery services in these settings has not yet been determined by the Ministry of Health. A number of policy questions relating to midwifery have yet to be resolved by the Ministry. These include practice sites, methods of remuneration and hospital privilege for Ontario midwives. ${ }^{192}$

To ensure the continuity of midwifery care between community and the hospital, it is essential that community-based midwives be permitted to accompany and care for their clients in hospitals. ${ }^{133}$ The Ontario government is currently reviewing the system of hospital governance under the Public Hospitals Acr ${ }^{144}$ The Ministry of Health expects that changes to the Public Hospitals Act will be consistent with the principles of the new regulatory model in the RHPA and will promote the role of midwilery in the health care system. ${ }^{195}$ A proposal to replace the present Medical Advisory Committee with a multidisciplinary "Professional Advisory Committee" to oversee hospital staff would serve to diffuse the traditionally dominant position of physicians in hospital governance. The IRCM has recommended revisions to the Act which would grant midwives hospital admitting and discharge privileges, as well as the ability to order laboratory work and provide primary care in hospitals within the scope of midwifery practice recognized in the Act.

R. Michelhorough. "Casc Rencws Longstanding Debale" (Glohe' \& Mail $(1,3$ November $|99|) \mathrm{Al}$ at AI- $\wedge 6$.

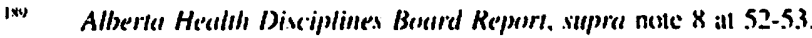

(a) McDenald Interview. sutpro note 49.

IvI IRCM. Suhmission (1) the Standing Committee on Secial Development, Exhibit No. 1/05/1.38 at I0 (14 August (90)1).

112

Anderson Interview. summa note 168; A. Burrows. Dehates. supra note 23. No. S-19 at S-618 122 August $($ (x)11. The Ontario Ministry of Health announced in March 1993. that three out-of-hospital. provincially-funded. birthing centres are expected to be licensed in 1994. Although the details of funding are under neview. midwives will be paid hy salary not "fec-for-service". Ontario Ministry of Health. News Release "Midwives Io Deliver Babics in Birthing Centres" 29 March 1993).

i.' IRCM. "Midwilery Practice in Hospitals Addressed in Bricf in Public Hospitals Act Review

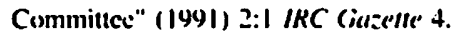

in R.S.O. 1990 . c. P-40.

1.6. Bohnen Intervieu. supro note 77: Burrows Interview. supra note 79. 
Ultimately, regardless of proposed changes to the Public Hospitals Act, decisions on whether midwifery service, or any other service, should be provided in a particular hospital will be made by individual hospital boards. Consequently, the attitudes of hospital administrators and medical staff will continue to affect the availability and range of midwifery service. The authority to determine who, within a profession, may be granted a hospital appointment and privileges will continue to rest with local boards. ${ }^{1 \%_{0}}$ Moreover, with regard to midwifery care in hospitals, the Ontario Hospital Association has stated that "within the defined scope of practice of midwifery... each hospital should have the right to establish its own policies, protocols and procedures with respect to the provision of that particular service." 197

For these reasons, many midwives and their supporters favour birthing centres as neutral alternative locations for midwifery practice. The Independent Health Facilities Act permits and governs the establishment in Ontario of community clinics and birthing centres independent of public hospitals. ${ }^{198}$ The standards of midwifery practice would provide for informed choice by clients and for obstetrical consultation and referrals. ${ }^{\mid(x)}$

Recently, interest in providing midwifery services in various settings, including hospitals and birthing centres, has grown due to the declining involvement of medicine in normal or low-risk obstetrics and an increasing concern over health care costs. ${ }^{211}$ For hospital administrators and obstetrical departments, in particular, the use of midwifery services represents a cost effective vehicle for normal obstetrics and continuous care. ${ }^{201}$ However, one hospital president has cautioned: ${ }^{202}$

With the idea of physicians giving up ohstetrics. comes another problem. When the rate of increase of physicians is double the rate of the population is there then an incentive for physicians to give primary obstetrical care over to other health care providers"?

\section{THE FUTURE INTEGRATION OF MIDWIFERY AS A REGULATED HEALTH PROFESSION WITHIN ONTARIO'S HEALTH CARE SYSTEM}

The Midwifery Act recognizes midwifery as an independent, self-governing profession of specialists in normal birth. The decision to grant legal, professional status to midwifery is part of a comprehensive revision of the delivery of health care in Ontario. Specifically, the introduction of midwifery "reflects current progressive trends toward community-based

Busrows. ihid.

Ontario Hospital Association. Presentation to the Standing Committec on Social Development on the RHPA. $199 /$ and the Heulh Professions Acts. 1991. Exhibit No. A 1/(15/2)43 at 7 (14 August 1991). R.S.O. 1990). c. I-3.

Toronto Birth Centro. Letter II) Elinor Caplan. Chair of the Standing Committee on S(xial Development. daled Augusi 30. 1991, in Exhihit No. A 1/05/139A (14 August 1991).

R.C. Walker. "A Multidisciplinary Public Hospital'?" (1990) II Hcalth L. Can. 14 all 14.

McDonald Intervicw, suprea note 49.

R.C. Walker. supra note 2000 at 14. 
care and consumer choice of care giver...[and] the increased desire of women and families to experience pregnancy and birth as normal healthy physiological processes." ${ }^{203}$

The RHPA and its companion professional Acts have been designed to provide high quality professional care while affording the public freedom of choice within a range of safe options. ${ }^{204}$ Under the reformed regulatory scheme, midwives and their clients will benefit from increased access to services and facilities within the health care system. Midwives and other regulated professions will be subject to the same provisions in the RHPA governing registration, discipline and competency. Midwives and their supporters have welcomed the new legislation as a sound balance of midwifery's professional independence and public accountability. ${ }^{205}$

Nevertheless, the new legislation will not complete the task of establishing and integrating midwifery as a regulated profession. ${ }^{2 k_{0}}$ The attitudes of some health care professionals presently working in pregnancy and childbirth care may hinder the integration of midwives into the structure of health care delivery. However, midwives do not seek to undermine or replace other health care practitioners. Instead, midwives intend to work as equal partners in Ontario's health care system to increase not decrease the choices available to women. An environment of trust and respect among health care professionals and the public is expected to evolve over time. ${ }^{317}$ The IRCM has stated: ${ }^{210 x}$

\footnotetext{
As the new and cxpanded health professions embratc their responsibilitics and rights under the Reguluted

Health Professioms A(t, the benefit to the consumer and the system will become obvious.... While we recognize that for sume of these professions the entry of a new primary care giver will require adjusiment of traditional expectations and familiar working structures, we are confident that the midwife will soon become a valued member of the health care team all over Ontario, as she is already in some communities and settings.
}

The ultimate objective of the Ontario legislation is to protect the public interest in health care. One of the means of achieving this aim is to establish parity among the various professions involved in the health carc system. Midwifery, after a long history of opposition by established medicine and of illegal status, is now recognized as an integral part of the health care system. As a regulated profession, midwifery has the ability to govern itself within the framework established in the RHPA and within the statutory scope of practice defined in the Midwifen Act.

IRCM. Submission to the Standing Committec on Streial Development, Exhibit No. N 1/05/138 at 7 (14 August 1991).

sas Siriking a Nent Balumce, supra note 46 at 2.

I1" K. Kaufman. Birth, supro note 22 at 1112.

3w. IRCM. Submission to the Standing Conmnittec on Sucial Development. Exhibit No. $N$ 1/15/1.38 at 11 (14 August 1991). 
The new regulatory model is intended to replace the physician-dominated, hierarchical delivery of health care by health practitioners. The RHPA and its companion professional Acts will be "living legislation" with ongoing review by the Health Professions Advisory Council and a planned review by the government in five years. ${ }^{2(n)}$

\section{CONCLUSION}

During centuries of midwifery care for pregnant women and their babies, midwives have traditionally viewed childbirth as an essentially normal process and not as an abnormal, pathological condition. Midwives see communication and decision-making as a shared responsibility between the midwife and the client. who is the primary decisionmaker. The Midwifen Act, which contains legal recognition of a broadly-defined, independent scope of practice, should enable midwives to preserve the integrity of midwifery care and to prevent the imposition of external views and methods of childbirth care.

It remains to be seen whether this legislation will achieve the objective of establishing midwifery as a regulated profession with a clear, autonomous scope of practice. While midwives may act autonomously within the bounds of practice, they lack the power to define the bounds of that autonomy which hinges on the concept of normal pregnancy, labour and delivery.

The scope of medical practice, as defined in the Medicine Act. 1991, does not merely overlap but envelopes that of midwifery. Furthermore, under the new scheme of controlled acts, physicians retain the exclusive authority, in the field of pregnancy and birth care, to diagnose abnormalities and to communicate a diagnosis. The statutory authority of physicians to diagnose and to communicate means that medicine, not midwifery, will draw the line between normal and abnormal pregnancy and childbirth. Therefore, the new legislation effectively vests in the profession of medicine the authority to control the scope and availability of "autonomous" midwifery.

While the new legislation has many commendable features such as its dynamic, open decision-making processes, its wide consultation with practitioners and consumers, its incorporation of alternative approaches to professional regulation and health care in the public interest, it remains a flawed foundation for achieving midwives' autonomy of practice. It is still not clear whether the RHPA and the Midwifery Act will promote or undermine the autonomy and integrity of midwifery. The legislation cannot immediately satisfy all the competing interests and views regarding midwifery's place in the health care system. Now, in the words of Frances Lankin, speaking as Ontario's Minister of Health: ${ }^{211}$ 
... A|fter so many years of having a review of these issues and of legislative development, we need a period of time of experience with the legislation in order to be able to judge whether the review itself got all the individual scopes of practices exactly right.

With the passage of the Midwifery Act and the related health professions Acts, it is necessary that the various professional governing colleges, hospital organizations and government bodies collaborate effectively to ensure appropriate access to midwifery care for women who choose it. In implementing the Midwifery Act, there is much to be done to ensure that the regulatory framework for the practice of midwifery represents an effective balance of quality and safety as well as consumer choice and professional autonomy which will promote the optimal delivery of midwifery services in Ontario. 